\title{
EIGHTEEN YEARS OF STEEL-BENTONITE INTERACTION IN THE FEBEX IN SITU TEST AT THE GRIMSEL TEST SITE IN SWITZERLAND
}

\author{
Jebril Hadi $^{1}{ }^{*}$, Paul Wersin $^{1}$, Vincent Serneels ${ }^{2}$, and Jean-Marc Greneche ${ }^{3}$ \\ ${ }^{1}$ Institute of Geological Sciences, University of Bern, Baltzerstrasse 3, 3012 Bern, Switzerland \\ ${ }^{2}$ Département de Géoscience, Université de Fribourg, chemin du Musée 4, Fribourg 1700, Switzerland \\ ${ }^{3}$ Institut des Molécules et des Matériaux du Mans (IMMM), UMR CNRS 6283, Université du Maine, 3 avenue Olivier Messiaen, \\ 72085 Le Mans, France
}

\begin{abstract}
Corrosion of steel canisters containing buried high-level radioactive waste is a relevant issue for the long-term integrity of repositories. The purpose of the present study was to evaluate this issue by examining two differently corroded blocks originating from a full-scale in situ test of the FEBEX bentonite site in Switzerland. The FEBEX experiment was designed initially as a feasibility test of an engineered clay barrier system and was recently dismantled after 18 years of activity. Samples were studied by 'spatially resolved' and 'bulk' experimental methods, including Scanning Electron Microscopy, Elemental Energy Dispersive Spectroscopy (SEM-EDX), $\mu$-Raman spectroscopy, X-ray Fluorescence (XRF), X-ray Diffraction (XRD), and ${ }^{57}$ Fe Mössbauer spectrometry, with a focus on Fe-bearing phases. In one of the blocks, corrosion of the steel liner led to diffusion of $\mathrm{Fe}$ into the bentonite, resulting in the formation of large (width $>140 \mathrm{~mm}$ ) red, orange, and blue colored halos. Goethite was identified as the main corrosion product in the red and orange zones while no excess $\mathrm{Fe}^{2+}$ (compared to the unaffected bentonite) was observed there. Excess $\mathrm{Fe}^{2+}$ was found to have diffused further into the clay (in the blue zones) but its speciation could not be unambiguously clarified. The results indicate the occurrence of newly formed octahedral $\mathrm{Fe}^{2+}$ either as $\mathrm{Fe}^{2+}$ sorbed on the clay or as structural $\mathrm{Fe}^{2+}$ inside the clay (following electron transfer from sorbed $\mathrm{Fe}^{2+}$ ). No other indications of clay transformation or newly formed clay phases were found. The overall pattern indicates that diffusion of Fe was initiated when oxidizing conditions were still prevailing inside the bentonite block, resulting in the accumulation of $\mathrm{Fe}^{3+}$ close to the interface (up to three times the original $\mathrm{Fe}$ content), and continued when reducing conditions were reached, allowing deeper diffusion of $\mathrm{Fe}^{2+}$ into the clay (inducing an increase of 10-12\% of the Fe content).
\end{abstract}

Keywords—Bentonite $\cdot$ Corrosion · Engineered Clay Barrier · Fe Diffusion · FEBEX Experiment · Grimsel Test Site · Steel Liner

\section{INTRODUCTION}

Many geological repository concepts for radioactive waste envision disposing of metallic waste-containing canisters in deep tunnels, using compacted bentonite as backfilling material (e.g. Nagra 2002; ANDRA 2005; SKB 2011; Posiva 2012). This smectite-rich material possesses favorable properties, such as large swelling capacity and retention capacity for radionuclides. In some cases (e.g. Swiss, Spanish, or French concepts) low-alloy steel waste-containing canisters will be used. Upon repository closure, the surrounding bentonite will be gradually saturated by the ingress of natural porewater from the surrounding host rock, and at the same time will experience elevated temperatures (up to $130^{\circ} \mathrm{C}$ ) originating from the radioactive decay of the waste. Steel canister corrosion will be initiated, eventually leading to the release of mobile dissolved $\mathrm{Fe}$ species reacting with the bentonite clay (Wersin et al. 2004; Bradbury et al. 2014).

A constantly growing set of studies is focused on the effects of corroding $\mathrm{Fe}$ on bentonite or on other clay materials (Wersin et al. 2008; Bradbury et al. 2014;

* E-mail address of corresponding author: jebril.hadi@geo.unibe.ch DOI: $10.1007 / \mathrm{s} 42860-019-00012-5$
Kaufhold et al. 2015). Most studies have been dedicated to small-scale laboratory systems, often designed to enhance Fe-clay interactions. Several corrosion-related processes affecting the barrier function of the bentonite backfill have been recognized, including (1) local cementation of bentonite via precipitation of $\mathrm{Fe}(\mathrm{II}) /(\mathrm{III})$ (oxyhydr)oxides (Carlson et al. 2007), (2) smectite dissolution via $\mathrm{pH}$ increase (Marty et al. 2010), (3) destabilization of the dioctahedral smectite structure (Lantenois et al. 2005) or (4) transformation of smectite to a non-swelling $\mathrm{Fe}$ phyllosilicate such as berthierine, cronstedtite, or odinite, by incorporation of diffusing $\mathrm{Fe}$ into the structure (Mosser-Ruck et al. 2010; Kaufhold et al. 2015), and (5) sorption of Fe on smectite, possibly followed by reduction of smectite structural Fe (Gehin et al. 2007; Soltermann et al. 2013; Latta et al. 2017) leading to changes of clay properties such as cationexchange capacity (CEC) or hydration (Stucki 2006). In turn, the properties of bentonite also seem to have an influence on the corrosion process (Kaufhold et al. 2015).

Comparatively few studies of steel-bentonite interaction were conducted under more realistic repository settings, i.e. low liquid/solid and Fe/clay ratios, larger scale, and longer times (e.g. in situ Long-Term Test of Buffer Material (LOT, Karnland et al. 2009), Alternative Buffer Material (Eng and Svensson 2007), Full-scale Engineered Barrier Experiment

Published online: 10 July 2019 
(FEBEX) Mockup (Martín et al. 2006), and FEBEX in situ test at the Grimsel Test Site (GTS) in Switzerland (FuentesCantillana et al. 2000)). Such experiments were conducted over timescales varying from years to decades. According to the experiments dismantled and studied so far, much less smectite alteration has been noted under such conditions (compared to controlled small-scale experiments), but magnetite, $\mathrm{Fe}$ (oxyhydr)oxides, and siderite were observed as corrosion products (Papillon et al. 2003; Carlson et al. 2007; Martin et al. 2008; Gaudin et al. 2009; Schlegel et al. 2010; Wersin et al. 2015). Despite the numerous investigations, the overall mechanisms of interaction between corroding steel and bentonite are still to be defined (Kaufhold et al. 2015). Uncertainties in predicting the stability of the bentonite backfill in contact with reactive metallic Fe components, therefore, persist, in particular regarding the mineralogical and hydraulic properties of the contact area between steel and clay (Perronnet et al. 2008).

The present study focused on the contact area between a corroding $\mathrm{Fe}$ source and compacted bentonite in the long-term (18 years) FEBEX in situ test at the GTS. This test was originally designed to demonstrate the feasibility of an engineered barrier system in granitic rock (Huertas et al. 2006). It did not aim specifically at studying the details of steel corrosion and ironbentonite interaction. Nevertheless, post-mortem analysis enabled valuable insight into these processes as indicated already after the first partial dismantling carried out in 2002 (see below). Therefore, after the final dismantling carried out in 2015, a strong focus of the investigation was on corrosion-related effects on the bentonite (Kober et al. 2017). The primary objective of the present study was the characterization of colored interaction zones observed in the bentonite block, newly formed $\mathrm{Fe}$ phases, and the effect of corrosion on the bentonite chemistry. The secondary objective was the development and optimization of analytical methods for characterizing the steel-clay contact areas, which could be applied later to the samples from further ongoing long-term in situ tests. An extended methodology combining spatially resolved (SEM-EDX and $\mu$-Raman spectroscopy) and bulk-type methods (XRF, XRD, and ${ }^{57} \mathrm{Fe}$ Mössbauer spectrometry) was employed.

\section{EXPERIMENTAL METHODS}

\section{The FEBEX in situ test}

The FEBEX in situ test was designed by the Spanish Radioactive Waste Management Organization (ENRESA) to demonstrate the feasibility of constructing horizontal engineered barrier systems, to explore potential design issues, and to understand better the thermo-hydro-mechanical (THM) and thermo-hydro-geochemical (THG) processes in the near field under a realistic repository setting with variable humidity and redox conditions and temperatures of $100^{\circ} \mathrm{C}$. The test involved a carbon steel (15Mo3 after DIN 17155, composition: 99.04 wt. \% Fe, 0.16 wt.\% C, 0.30 wt.\% Si, and 0.60 wt.\% Mo) liner surrounded by a clay barrier, and enclosing two heaters (Fig. 1a). In total, 300 tons of bentonite were homogenized for construction of the FEBEX in situ test, and compacted to blocks of $20 \mathrm{~kg}$. The project was initiated in 1994 and construction finished in 1996. Construction of the experiment took 3.5 months. Heating was started in 1997 (after a preoperational stage of 4 months between closure of the plug and heating), and a partial dismantling was performed in 2002. The first heater was turned off and removed, replaced by a dummy cell, blocks of bentonite were collected, and the experiment was closed again. The second dismantling started in 2015 and continued until 2016. Portions of the steel pieces retrieved (liner, heater, dummy cell, extensometers, fissurometers, drilling rods, cable ducts, etc.) showed clear corrosion features. The impact of corrosion could also be observed in some zones of the bentonite surrounding those corroded objects, appearing as concentric and colored (red, orange, blue) halos (e.g. Fig. 1b). A complete description of the experiment has been published (Fuentes-Cantillana and García-Siñeriz 1998; Fuentes-Cantillana et al. 1998, 2000; Lanyon and Gaus 2017).

\section{On-site and in-lab sampling activities}

The present study focused on two blocks originating from the same section of the experiment, which was located between the two heaters during the first sequence of the experiment and, later after the partial dismantling, between the second heater and the dummy cell replacing the first heater (Fig. 1a). Temperatures in the range 30 to $60^{\circ} \mathrm{C}$ were likely reached in this location of the experiment (Fuentes-Cantillana and GarcíaSiñeriz 1998). A final water content of $26 \mathrm{wt} \%$ was determined in this area of the experiment (Villar et al. 2016), showing a notable increase compared to the initial state (13 wt.\% upon construction, Fuentes-Cantillana and GarcíaSiñeriz 1998). Dismantling proceeded layer by layer, and the presence of a colored corrosion halo was observed as soon as the bentonite layer separating the dummy cell and the second heater was reached (Fig. 1b). This halo was asymmetric, and preferentially located on the upper left part of the liner, while the opposite side of the liner appeared almost unchanged by corrosion. In fact, a plastic sheet was placed between the granite and the lower right part of this section of the bentonite barrier during construction of the FEBEX experiment. This sheet was inadvertently left behind and further hindered direct water ingress, and thus Fe diffusion to this area of the experiment (Villar et al. 2016). Two bentonite blocks of $\sim 22 \mathrm{~kg}$ each $(\sim 480 \mathrm{~mm} \times 125 \mathrm{~mm} \times 220 \mathrm{~mm}$ length $\times$ width $\times$ height $)$ were extracted from the bentonite backfill, one from the strongly impacted area (block BM-B-41-1, Fig. 1d) and the other from the much less impacted area (block BM-B-41-2, Fig. 1c). These blocks were only partially exposed to the ambient atmosphere (one side was exposed and covered by a plastic sheet to limit drying and oxidation) for a few hours before they could be extracted, vacuum-packed, and transported to the laboratory. Using a band saw (bi-metal M51, WESA-Sägen H. Weber AG, Menziken, Switzerland), $20 \mathrm{~mm}$ thick slabs 

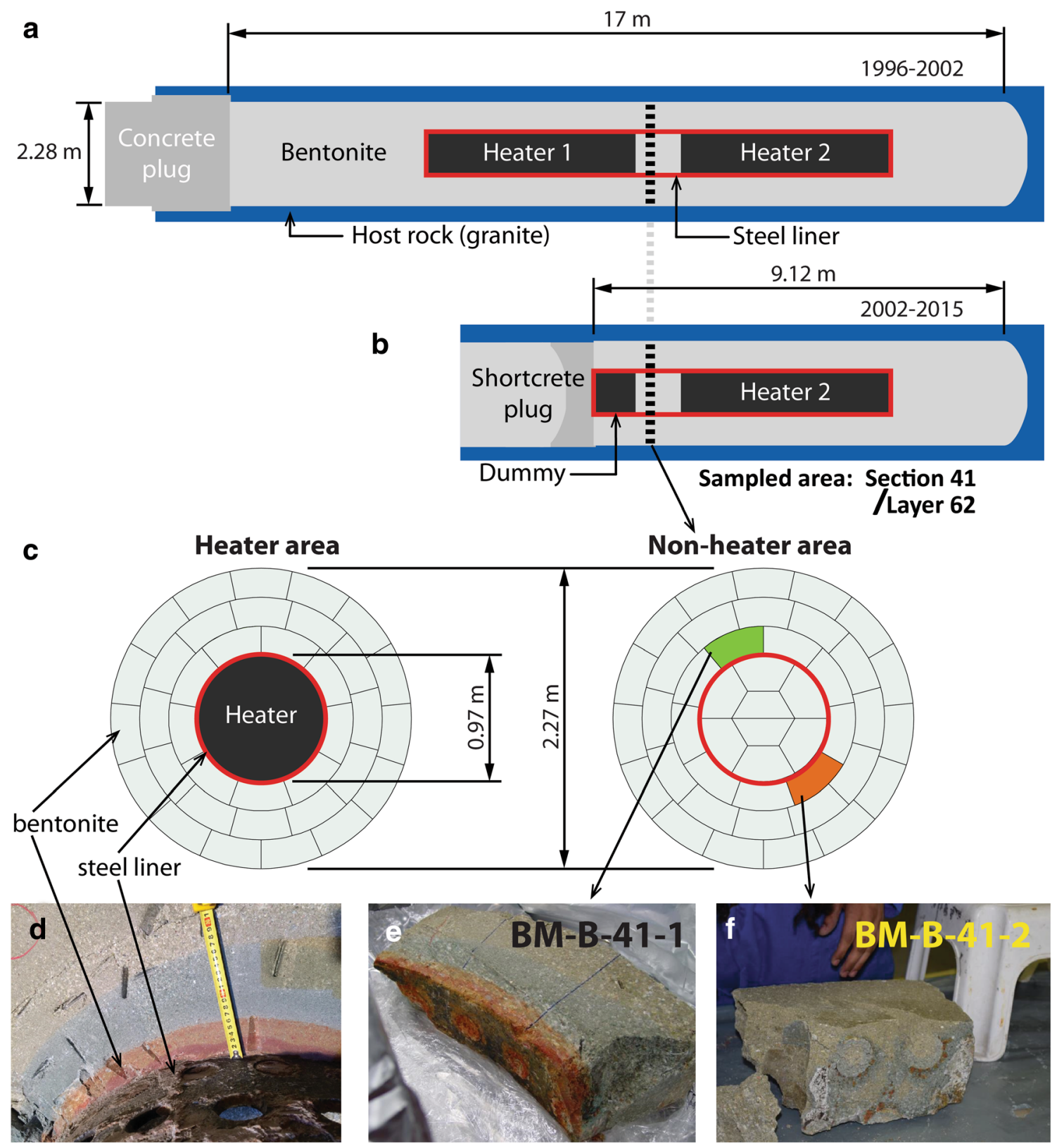

Fig. 1 Overall layout of FEBEX in situ test (a) before (1996-2002) and (b) after (2002-2015) partial dismantling. (c) Cross-sections of the heater and non-heater areas, indicating the location of the sampled blocks. (d) Corrosion-impacted bentonite block still in place at the contact with the steel liner. (e-f) Studied blocks BM-B-41-2 and BM-B-42-2

were extracted from the middle part of each sample block and used for the present study (e.g. Fig. 1e).

Two different sampling routines were further applied. First, six contiguous slabs (36-37 mm long, $20 \mathrm{~mm}$ wide) were cut from the BM-B-41-1 block and vacuum-embedded with epoxy resin (Araldite ${ }^{\circledR}$ XW396/XW397, Astorit AG, Einsiedeln, Switzerland), then they were polished using diamond grinding papers (using Apex DGD 70, 45, 30, and $15 \mu \mathrm{m}$, and finally using a $6 \mu \mathrm{m}$ diamond suspension; Buehler, Lake Bluff, Illinois, USA) and petroleum (odorless petrol; Univar AG, Birmensdorf, Switzerland). The polished surfaces formed a profile perpendicular to the interface and cross-cutting the entire block (Fig. 2a). They were analyzed using SEM-EDX to obtain electron backscattering images and chemical maps, and to establish chemical profiles of the major elements perpendicular to the interface. Raman spectroscopy was also employed to identify some of the accessory phases present in the matrix, focusing on Fe-bearing species. One shorter polished section was prepared from the significantly less impacted block BM-B-41-2 (Fig. 2b).

A large portion of one slab of block BM-B-41-1 was powdered in a glovebag with a 95:5 $\mathrm{N}_{2}: \mathrm{H}_{2}$ atmosphere (Coy 

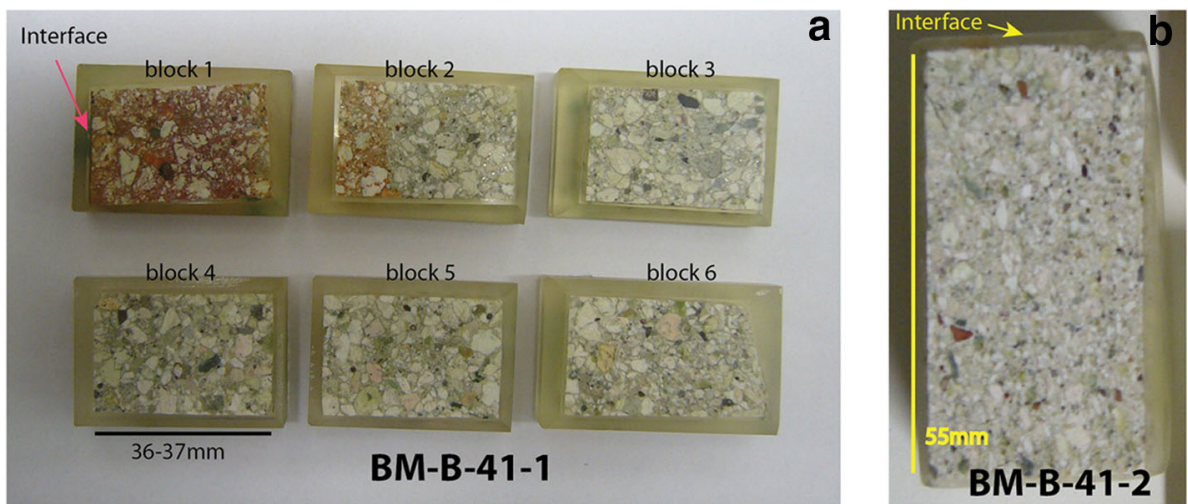

Fig. 2 (a) Six contiguous polished surfaces of a cross section of block BM-B-41-1 and (b) one polished section of block BM-B-41-2

Laboratory Product Inc., Grass Lake, Michigan, USA). Once the "crust sample" (the actual contact with the liner) was scraped off (few hundreds of micrometers thick), 5-6 mm thick layers parallel to the interface were progressively cut off the slab (using a ceramic knife) and stored in individual tubes. Thirty different samples ( $\sim 20 \mathrm{~g}$ each) were separated (i.e. up to $18 \mathrm{~cm}$ deep in the block). Samples were named after the color of the zone they were extracted from (B: blue, O: orange, R: red, G: green) and the order of sampling. The outermost layer was also powdered. Chemical analysis (XRF) was performed on all powdered samples, and selected samples were characterized by transmission ${ }^{57} \mathrm{Fe}$ Mössbauer spectrometry and XRD (12 samples, including the raw bentonite).

A portion of the raw bentonite block was also crushed gently by hand in ambient atmosphere and various colored aggregates were separated (Fig. 3). They were further crushed by hand in an agate mortar and analyzed using XRD to determine the mineralogical composition.

\section{Analytical methods}

SEM-EDX analyses The uncoated sample surface was examined in a SEM (EVO-50 XVP, Carl Zeiss AG, Oberkochen, Germany) equipped with an EDAX® Sapphire light-element detector (AMETEK, Berwyn, Pennsylvania, USA) in low vacuum mode (10-20 Pa) with a beam acceleration of $20 \mathrm{kV}$, a sample current of $500 \mathrm{pA}$, and a working distance of $8.5 \mathrm{~mm}$. The beam current was adjusted to yield a dead time of $8-15 \%$ for EDX analysis. EDX element maps with a resolution of $128 \times 100$ pixels were acquired using a dwell time of $200 \mu \mathrm{s} /$ pixel. Mappings were conducted with a magnification of 80 , which results in pixel size of $\sim 11 \mu \mathrm{m}^{2}$ and maps of $\sim 1.5 \mathrm{~mm} \times 1.1 \mathrm{~mm}$. Contiguous mappings were collected in series in order to obtain large-scale mosaic-like elemental mappings. Mapped elements generally included $\mathrm{C}, \mathrm{O}$, $\mathrm{Na}, \mathrm{Mg}, \mathrm{Al}, \mathrm{Si}, \mathrm{P}, \mathrm{S}, \mathrm{Cl}, \mathrm{K}, \mathrm{Ca}, \mathrm{Ti}$, and $\mathrm{Fe}$. The total grid dimension was usually 26-27 mappings along the $\mathrm{x}$ axis and eight mappings along the $y$ axis (total dimensions of $\sim 34$ $\mathrm{mm} \times 9 \mathrm{~mm}$ ). Given the parameters of analysis (resolution, dwell time), the acquisition time per block was $\sim 12 \mathrm{~h}$. Output data from the operating software (Smartsem ${ }^{\circledR}$ by ZEISS for the SEM part and Genesis ${ }^{\circledR}$ by AMETEK for the EDX) were collected and treated with a Matlab (MathWorks, Natick, Massachusetts, USA) homemade algorithm in order to establish chemical profiles, large scale elemental mappings, and backscatter images.

In the present study, the main data obtained from the SEMEDX survey are presented as "Al-normalized" chemical profiles of the major elements ( $\mathrm{Si}, \mathrm{Fe}, \mathrm{Mg}, \mathrm{Ca}, \mathrm{Na}, \mathrm{K}$, and S). Such a diagram represents the atomic ratio of a given element over $\mathrm{Al}$ as a function of the distance to the interface. The main assumption underlying this "Al-normalization" procedure is that, amongst the probed elements, $\mathrm{Al}$ is the least likely to change in terms of amounts and spatial localization (Ackermann 1980; Luoma 1990). As it is the least likely element to be dissolved and transported elsewhere under the conditions of the experiment, it can, thus, be used as a proxy for tracking the local variations of all the other probed elements relative to the original bentonite. The so-called "Al-normalized" values were computed directly from the quantification results (Lábár and Török 1992; Trincavelli et al. 2014). For a given element, each point of the profile represents the average ratio of the content in this element over the $\mathrm{Al}$ content of a given column of the analysis grid. The error bars account for twice the standard deviation. In the case of Fe, mapped sectors containing large $(0.1-1 \mathrm{~mm})$ goethite grains from the original bentonite matrix were not included in the profile (detailed further below). Raw EDX data were corrected using individual Standard Element Coefficients (SEC) factors for each element. These factors were determined from the EDX analysis of six different raw bentonites of very similar composition for which reference XRF data were also available (Svensson et al. 2011).

$\mu$-Raman spectroscopy Raman spectroscopy was performed with a Jobin Yvon LabRAMHR800 instrument (HORIBA Scientific, Kyoto, Japan), consisting of a BX41 confocal microscope (Olympus, Shinjuku, Japan) coupled to an $800 \mathrm{~mm}$ focal length spectrograph. A non-attenuated $\mathrm{He}-$ Ne laser (20 mW, polarized 500:1) with an excitation wavelength of $632.817 \mathrm{~nm}$ (red) was focused on the sample surface and the Raman signal was collected in reflection mode. The 

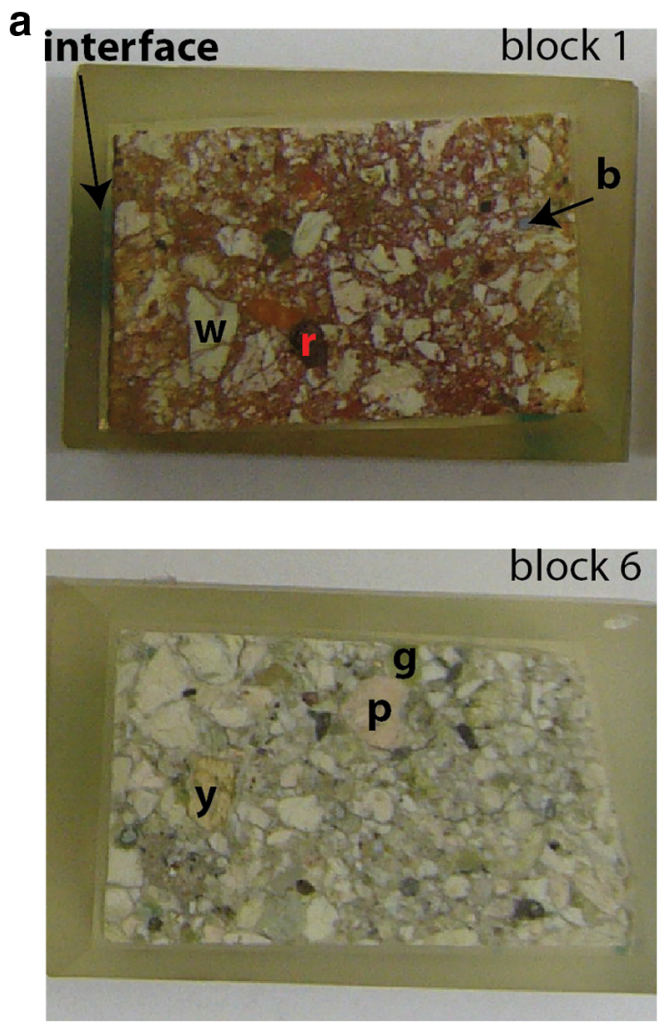

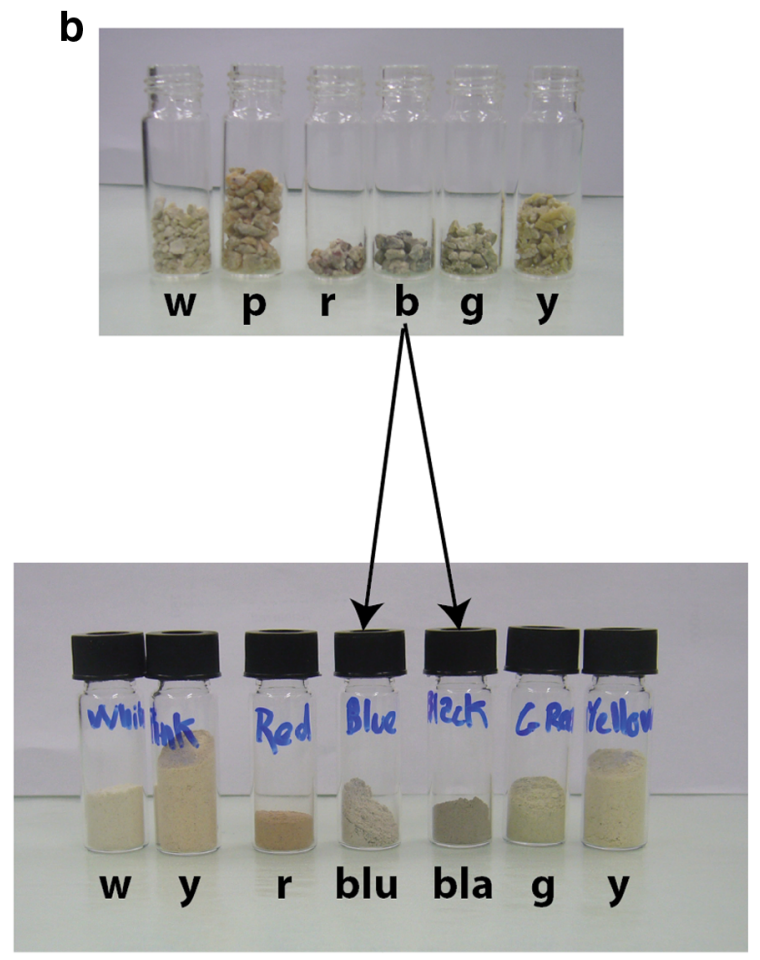

Fig. 3 (a) Two polished sections from block BM-B-41-1 and (b) color aggregates that were collected in the raw material and powdered. Letters indicate the color of the sample (w: white, p: pink, r: red, blu: blue, bla: black, g: green, y: yellow)

sampled volume was a few $\mu \mathrm{m}^{3}$ using a $100 \times$ objective lens. Spectra were measured in Raman shift intervals of 150 to $1400 \mathrm{~cm}^{-1}$ in five steps of $250 \mathrm{~cm}^{-1}$. Acquisition time for each step was $2 \times 15$ s, i.e. $2.5 \mathrm{~min}$ in total. Acquisition time was doubled for some analyses in the clay matrix. The spectra were recorded with Labspec V4.14 software (HORIBA Scientific). Identification of the species was done using the spectra library included in the HORIBA Edition of the KnowItAll® (Bio-Rad Laboratories AG, Cressier, Switzerland). The spectra presented in this report indicate the name(s) of identified species and corresponding reference number(s) in the library, which actually combines several entries for inorganics, minerals, and gemstones from Minlab v3 or RRUFF (Lafuente et al. 2015).

$X R F$ analyses Glass pellets were made by fusing a 1:10 mixture of sample powder and Li-tetraborate at $1150^{\circ} \mathrm{C}$ (Merck, New Jersey, USA). XRF analyses of major elements were performed on a PW 2400 spectrometer (Koninklijke Philips N.V., Amsterdam, Netherlands) and corrected with the internal Philips software X40 on the basis of a set of international rock standards. Loss on ignition (LOI) was determined by mass difference before and after fusing. Water content was determined during the same process $\left(105^{\circ} \mathrm{C}\right.$ for $\left.2 \mathrm{~h}\right)$.

\footnotetext{
${ }^{57} \mathrm{Fe}$ Mössbauer spectrometry The Mössbauer spectra were recorded at room temperature (RT, $300 \mathrm{~K}$ ) and at $77 \mathrm{~K}$
} using a constant acceleration spectrometer (driving unit supplied by WissEl GmbH, Germany) and a ${ }^{57} \mathrm{Co}$ source dispersed in a Rh matrix. Velocity calibrations were carried out using an $\alpha$-Fe foil at RT. The values of the hyperfine parameters were refined using a least-squares fitting procedure (MOSFIT homemade unpublished program, Le Mans Université, France) with a discrete number of independent quadrupolar doublets and magnetic sextets composed of Lorentzian lines. The values of isomer shift (I.S.) are reported relative to that of the $\alpha$-Fe spectrum obtained at RT. The proportions of each $\mathrm{Fe}$ species are proportional to the relative spectral area. This is because the f-Lamb-Mössbauer factors which correspond to the fraction of gamma rays emitted and absorbed without recoil are assumed to be identical for the different phases present in the samples and for the different $\mathrm{Fe}$ species present in the same phase (Mössbauer 1958; Tzara 1961; Gütlich et al. 2011).

All observed quadrupolar doublets stand for paramagnetic high-spin octahedral $\mathrm{Fe}$ (further referred to as "para-Fe"), while all magnetic sextets stand for magnetically ordered species (in octahedral coordination as well, further referred to as "mag-Fe"). In addition, it is important to emphasize that the quadrupolar component may in part be attributed to superparamagnetic species originating from very fast relaxation phenomena: it is, thus, necessary to compare Mössbauer spectra recorded versus different temperatures and/or in the presence of an external magnetic field. Goethite and hematite in particular display hyperfine structures which are strongly 
dependent on the crystalline grain size, the distance between adjacent grains, and temperature (Vandenberghe and De Grave 2013). In the present study, this temperature dependency was used to discriminate between "large" grains (or aggregates) of goethite or hematite ( $>\sim 50 \mathrm{~nm}$, magnetically ordered at room temperature and $77 \mathrm{~K})$, "medium-sized" grains $(\sim 5-50 \mathrm{~nm}$, paramagnetic at room temperature, but magnetically ordered at $77 \mathrm{~K}$, i.e. superparamagnetic), and "small" grains $(<\sim 5 \mathrm{~nm}$, paramagnetic at both temperatures, thus much more difficult to discriminate from other species such as the clay structural $\mathrm{Fe}(\mathrm{III}))$. In addition, the extent of the hyperfine magnetic field $\left(B_{\mathrm{hf}}\right)$ and of quadrupolar splitting (Q.S.) enable discriminating goethite from hematite (the latter generally exhibits a stronger $B_{\mathrm{hf}}$ and a higher Q.S.).

XRD analyses Studies of samples from block BM-B-41-1 were conducted using an Anton Paar domed sample holder for air-sensitive materials equipped with a polycarbonate dome (Anton Paar GmbH, Graz, Austria). The powdered samples were loaded on the sample holder in the anaerobic chamber, the surface was flattened with a glass slide and the dome was closed before the samples were removed from the chamber. The raw bentonites were also analyzed without the dome. The samples were analyzed with a X'Pert PRO X-ray diffractometer (PANalytical, Almelo, Netherlands) and recorded using $\mathrm{CuK} \alpha$ radiation with a wavelength of $1.54 \AA$ and an X-ray tube operated at $40 \mathrm{~mA}$ and $40 \mathrm{kV}$. The samples were scanned from 5 to $60^{\circ} 2 \theta$ using a step size of $0.0167^{\circ} 2 \theta$ and a time of $10 \mathrm{~s}$ per step, with automated divergence slits. Samples were spun during the measurement, at a rate of one revolution every $8 \mathrm{~s}$. Raw material and colored fractions isolated from raw material (Fig. 3) were analyzed without the dome.

\section{RESULTS}

\section{Polished blocks}

The SEM-EDX investigation enabled the establishment of a chemical mapping of the major elements (including $\mathrm{Si}, \mathrm{Al}$, $\mathrm{Fe}, \mathrm{Mg}, \mathrm{Ca}, \mathrm{Na}, \mathrm{K}, \mathrm{S}$, and Ti) on a large portion of the polished section (a total surface of $22 \mathrm{~cm}^{2}$ for block BM-B-41-1 and $4 \mathrm{~cm}^{2}$ for block BM-B-41-2). Results are presented as "Alnormalized" chemical profiles of the major elements perpendicular to the steel-bentonite interface (Figs. 4 and S1). Reference values inferred from inter-laboratory XRF analysis of the raw material are displayed on the diagram (reference data from Kober and Van Meir 2017). A "bulk" value is also indicated that corresponds to the average SEM-EDX measured value in the outermost $4 \mathrm{~cm}$ of the studied block.

\section{Chemical profiles of major elements in block BM-B-41-1}

The data show no net changes in $\mathrm{Si} / \mathrm{Al}$ throughout the entire profile relative to the original material. Localized peaks in Si content can be attributed to the presence of large grains of Si-rich phases in the bentonite matrix (e.g. quartz, cristobalite, tridymite, Opal CT). EDX and XRF data are very consistent with each other.

In addition, EDX data indicate no net changes in $\mathrm{Mg} / \mathrm{Al}$ and $\mathrm{Ca} / \mathrm{Al}$ relative to the original material. However, fluctuations in $\mathrm{Mg}$ and $\mathrm{Ca}$ content are less pronounced in the vicinity of the interface (at distance $<100 \mathrm{~mm}$, Fig. $4 \mathrm{c}, \mathrm{d}$ ) than in the rest of the block. The XRF data on powdered samples indicate a slight decrease in $\mathrm{Mg}$ and $\mathrm{Ca}$ towards the interface, but this is within analytical uncertainty.

Regarding $\mathrm{K}$ and $\mathrm{S}$ contents, data indicate no changes relative to the raw material. A slight decrease was observed by EDX but this remains within the uncertainty of the reference data. The small and constant difference between XRF and EDX data can be attributed to an underestimated SEC factor for these two elements and their lower contents close to or below the quantification limit of EDX. The very small $\mathrm{S}$ content $(<0.1 \mathrm{wt} . \%)$ indicates that the pyrite content in the FEBEX bentonite is also very low. The $\mathrm{S}$ peak visible at a distance of $\sim 160 \mathrm{~mm}$ is due to the presence of a large gypsum (or anhydrite) grain.

The drop in $\mathrm{Na}$ content toward the heater is more pronounced and was observed throughout the entire profile. As found for the K and S contents, the SEC factor may be slightly underestimated, given the difference between EDX and XRF data.

The most obvious changes were observed in the $\mathrm{Fe} / \mathrm{Al}$ ratios. Data clearly indicate a progressive increase of Fe content moving from $\sim 140 \mathrm{~mm}$ from the interface to the interface itself. A very slight decrease in Fe content was observed at a greater distance but it fell within the uncertainty of the reference data. The data, thus, indicated no changes in that area.

\section{Comparison between blocks BM-B-41-1 and BM-B-41-2}

Chemical profiles of all the major elements in the visually significantly less impacted block BM-B-41-2 showed no change relative to the original material (Fig. S1). All profiles showed no consistent deviation trend from the reference value.

\section{Accessory Fe phases in the bulk of FEBEX bentonite}

According to a previous characterization on raw FEBEX material (Villar et al. 2006), at least $80 \%$ of Fe should be associated with clay minerals. Still, a great variety of accessory Fe bearing species can be found. The identification of these species is, however, rare in the literature. Better knowledge is important in order to establish a profile of the "background $\mathrm{Fe}$ " present in the bentonite and to understand the changes in Fe content in the vicinity of the interface with the liner. Raman spectroscopy was attempted primarily to identify Fe accessory minerals present in the FEBEX material, occurring as micrometer to millimeter size crystals and which were easy to spot from microscope images. Raman spectroscopy is more difficult to apply for the clay matrix because of high fluorescence levels. Mixing with epoxy resin further complicates such 

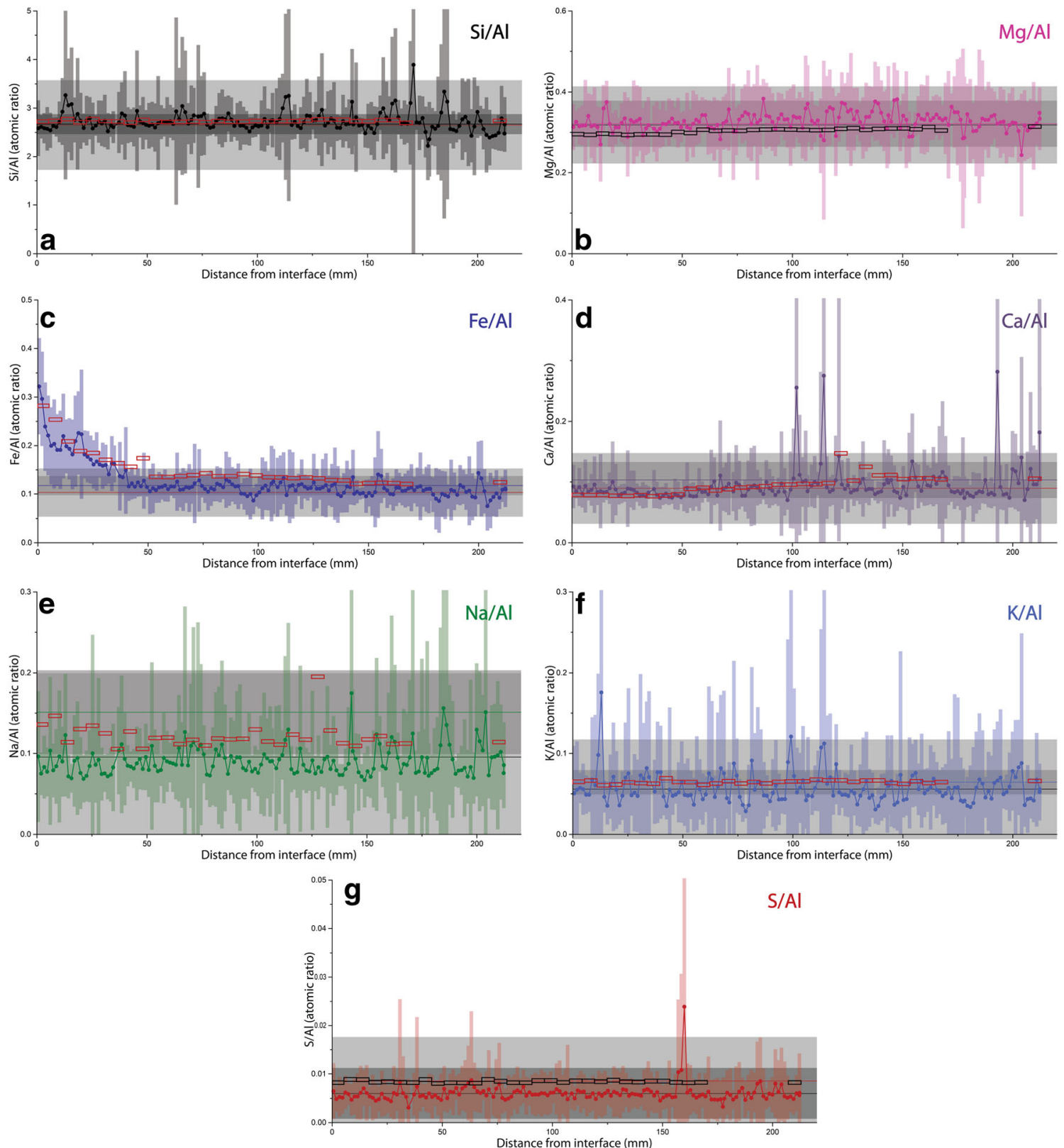

Fig. 4 "Al-normalized" chemical profiles of $\mathrm{Si}, \mathrm{Fe}, \mathrm{Mg}, \mathrm{Ca}, \mathrm{Na}, \mathrm{K}$, and $\mathrm{S}$ in block BM-B-41-1 from section 62. Empty rectangles represent XRF values on powdered samples. Horizontal lines of same color as data set represent average reference value measured in raw material, dark gray areas account for $2 \times$ the standard deviation on several measurements done in different laboratories (reference data from Kober and Van Meir 2017). Horizontal lines of contrasting color represent average "bulk" value in the outermost area of the block (between distance of $180 \mathrm{and} 220 \mathrm{~mm}$ ), light gray areas account for $2 \times$ the standard deviation

analysis, as the background signal becomes even higher. Various original Fe-rich phases were scattered in the FEBEX matrix. Only a fraction could be discriminated easily and identified by Raman spectroscopy (e.g. Fig. 5).

The main accessory Fe-bearing phase encountered in the FEBEX bentonite is goethite (Fig. 5a,b and Fig. 7a). It can be found as very large grains (from a few micrometers to more than $1 \mathrm{~mm}$, e.g. Fig. 5a,b and Fig. 7a). The eight mapped sectors where the four largest grains were found were not taken into account when establishing the chemical profile of Fe (over a total of 1256 mappings). Magnetite was found commonly in the core of the larger grains (Fig. 5a,c). The second easily identifiable $\mathrm{Fe}$ phase is ilmenite which was found in smaller (from a few micrometers to $>1 \mathrm{~mm}$ ) grains.

A notable quantity of accessory Fe species appears to be present as submicronic grains enclosed in other accessory 

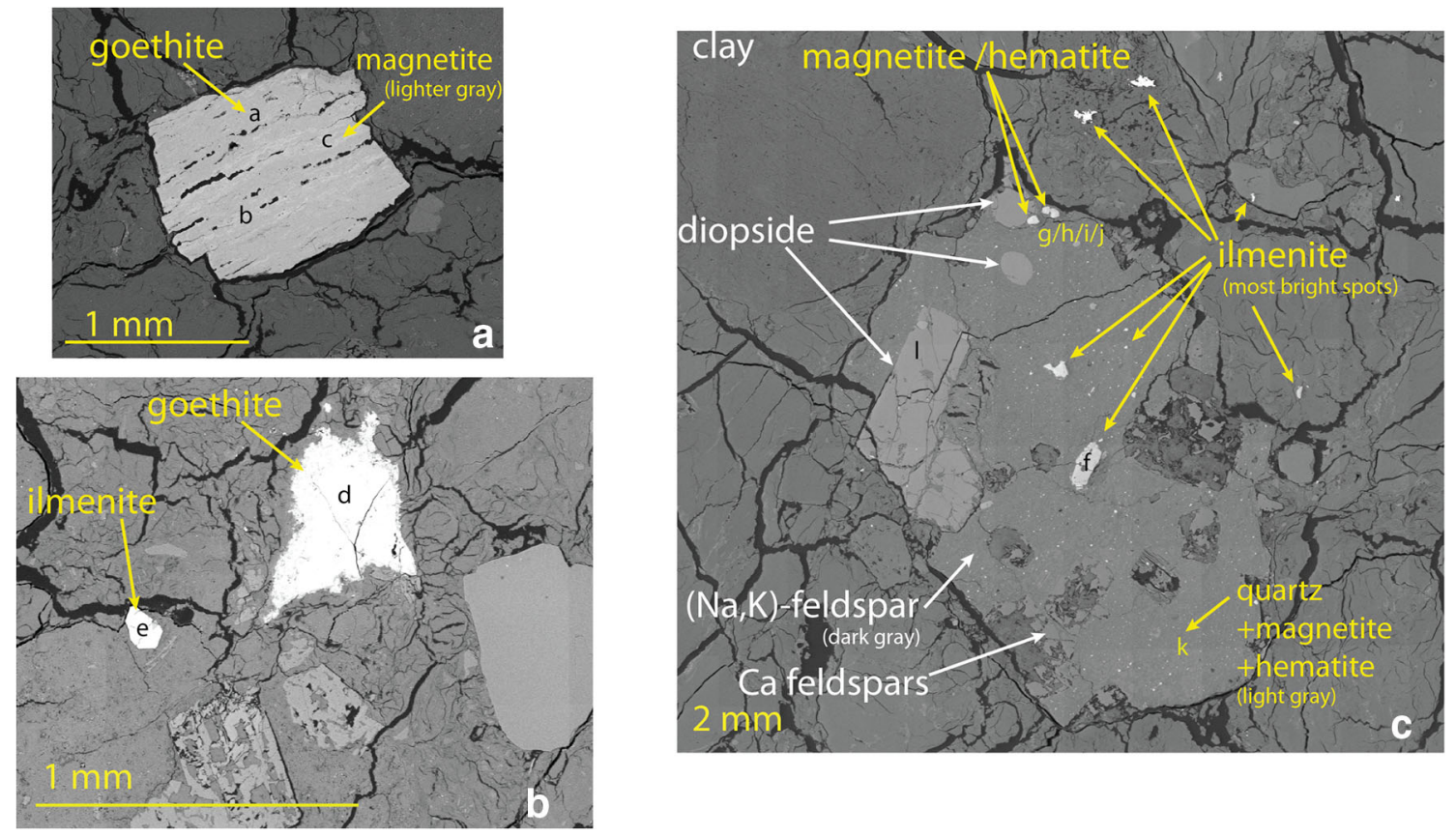

Fig. 5 SEM pictures of some ferruginous minerals found in the FEBEX matrix. Letters indicate spots where Raman spectroscopy was performed (some spectra are shown in Fig. 6)

minerals, making them more difficult to discriminate on chemical mappings and SEM images. For instance, large grains of $\mathrm{Na}-\mathrm{K}$ feldspars intermingled with quartz (Fig. 5c) were found containing medium (few $\mu \mathrm{m})$ to large $(100 \mu \mathrm{m})$ grains of either ilmenite or Fe oxides. These Fe oxides (referred to as "hematomagnetite" in Fig. 5c) display a core of magnetite (Fig. 6g) and a shell of low crystalline hematite-magnetite mixture (Fig. 6j). The quartz grain studied (Fig. 5c) also contains a significant quantity of $\mathrm{Fe}$ occurring as magnetite and various forms of more crystalline hematite (Fig. 6k).

\section{Fe accumulation at the interface}

The largest goethite crystals observed in the vicinity of the interface with the liner (e.g. Fig. 7a, the rim of the block is seen at the left side of the picture) can be inferred to be part of the original accessory phases, based on their large size and on texture (the mapped sector containing these grains was omitted when establishing the chemical profile of Fe displayed in Fig. 4 and Fig. S1). Other bright spots (or lines) were observed only in the red zone and, especially, close to the interface. These features point to areas where additional $\mathrm{Fe}$ species from the corroding liner tend to accumulate. The few clear Raman spectra collected in this zone indicate that the main Fe-bearing species is goethite (Fig. $7 \mathrm{n}$ ). Data also show a clear contrast between the Feenriched clayey part of the bentonite and zones where no net $\mathrm{Fe}$ accumulation was observed (Fig. 7b). A clear contrast can also be observed by eye as the Fe-enriched clay appears red, while the other zone free of additional $\mathrm{Fe}$ appears as unaffected white spots (see block 1 of sample BM-B-41-1 in Figs. 2 and 3). The strong red coloration of the bentonite correlates well with the area of goethite accumulation. The white zones are in fact mainly composed of smectite and amorphous silica (further presented in next section).

\section{Powdered samples}

\section{XRD analysis of colored fractions collected from raw material}

Data collected on seven different colored aggregates isolated from raw FEBEX bentonite (Fig. 3) were compared to the bulk raw material (Fig. S2). Some notable features are outlined. A list of identified species and their relative contribution, compared to the raw material, is also reported (Table 1).

The line near $6-7^{\circ} 2 \theta$ corresponds to the 001 basal reflection of the smectite(s) present in FEBEX bentonite. In standard conditions, i.e. $30-50 \% \mathrm{RH}, 25^{\circ} \mathrm{C}$, sodic montmorillonites display a basal spacing of $\sim 12 \AA$ while calcic ones display a basal spacing of $\sim 15 \AA$ because of the presence of one supplementary water layer in the interlayer (Fernandez et al. 2004; Ayari et al. 2007). Mg exchanged montmorillonites display a slightly smaller $(14.7 \AA)$ basal spacing than that of Ca. These values are, however, valid in wet conditions and would, in fact, be lower in drier conditions (as the thickness of the water layer decreases).

Raw FEBEX bentonite displays an average basal spacing of $14.6 \AA$. This is consistent with the exchangeable population in the pristine material (Villar et al. 2006), dominated by $\mathrm{Ca}$ (37-43 meqg ${ }^{-1}$ ) and $\mathrm{Mg}\left(31-32\right.$ meq g $\left.^{-1}\right)$, and containing less $\mathrm{Na}\left(24-27 \mathrm{meq} \mathrm{g}^{-1}\right)$ and $\mathrm{K}\left(2-3 \mathrm{meq} \mathrm{g}^{-1}\right)$. The various colored aggregates clearly display a different mineralogical composition. Light colored aggregates are richer in smectite than the bulk raw material (yellow $>$ pink $>$ white), while the dark 

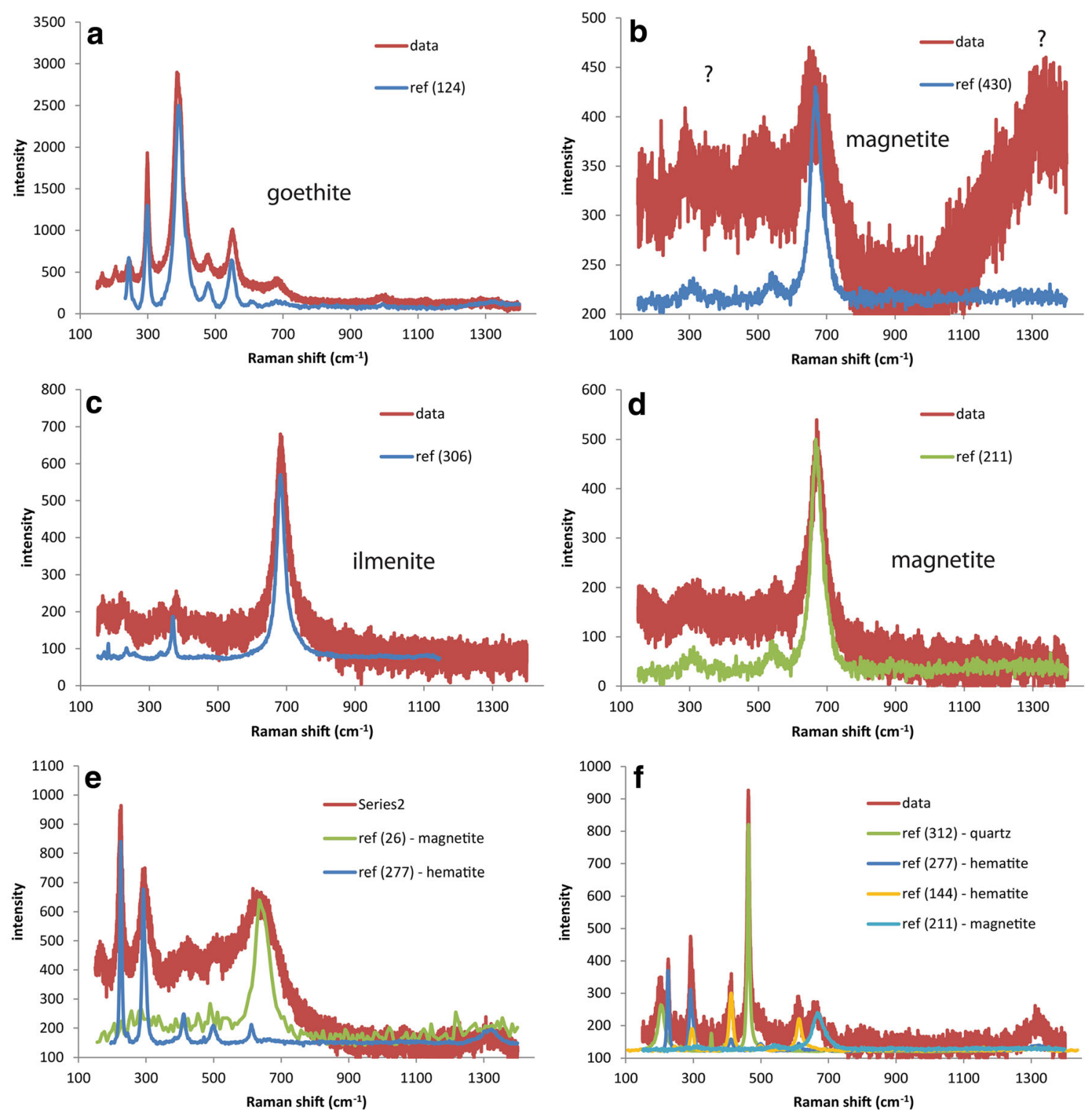

Fig. 6 Raman spectra collected at spots indicated in Fig. 5

colored aggregates are in fact much lower in smectite (green > red $>$ black $>$ blue). A small shift was observed between the positions of the 001 line, accounting for a basal spacing varying between $14.4 \AA$ in dark colored aggregates and $15.0 \AA$ in light colored ones. This may be explained by the slight variation in the composition and/or structure of the clay interlayer. Villar et al. (2006) previously observed that the majority of the bulk material (>90\%) consists of illite-smectite mixed layers (10-15\% of illite). No attempt to decipher the presence of interstratification was made in the present work. The present data, however, show that the main clay mineral is montmorillonite. The lower clay content of dark colored aggregates in fact correlates well with their greater content of quartz (green < red $<$ blue $<$ black) and silica polymorphs (cristobalite, tridymite, Opal CT; red $\sim$ black $<<$ blue). This content is also

consistent with the fact that these aggregates are notably harder than the light colored ones.

Another significant difference was seen regarding the accessory minerals, indicated by the reflections at slightly higher angles $\left(8.77-8.88^{\circ} 2 \theta\right)$. These reflections are due to the basal reflections of certain clay minerals that display smaller $d$ spacings (9.9-10.1 $\AA$ ) than those of smectites due to the absence of interlayer water. This is explained by the presence of micas, or more probably illite, as a better match with reference patterns is often found for illite. The presence of a range of micas (biotite, sericite, muscovite) was noted in a previous characterization of the FEBEX bentonite (Villar et al. 2006). The present results indicate that such phases (mica and/or discrete illite aggregates) are more likely to be found in the dark colored aggregates (red $\approx$ blue $<<$ black), which are in fact poor in smectites. 

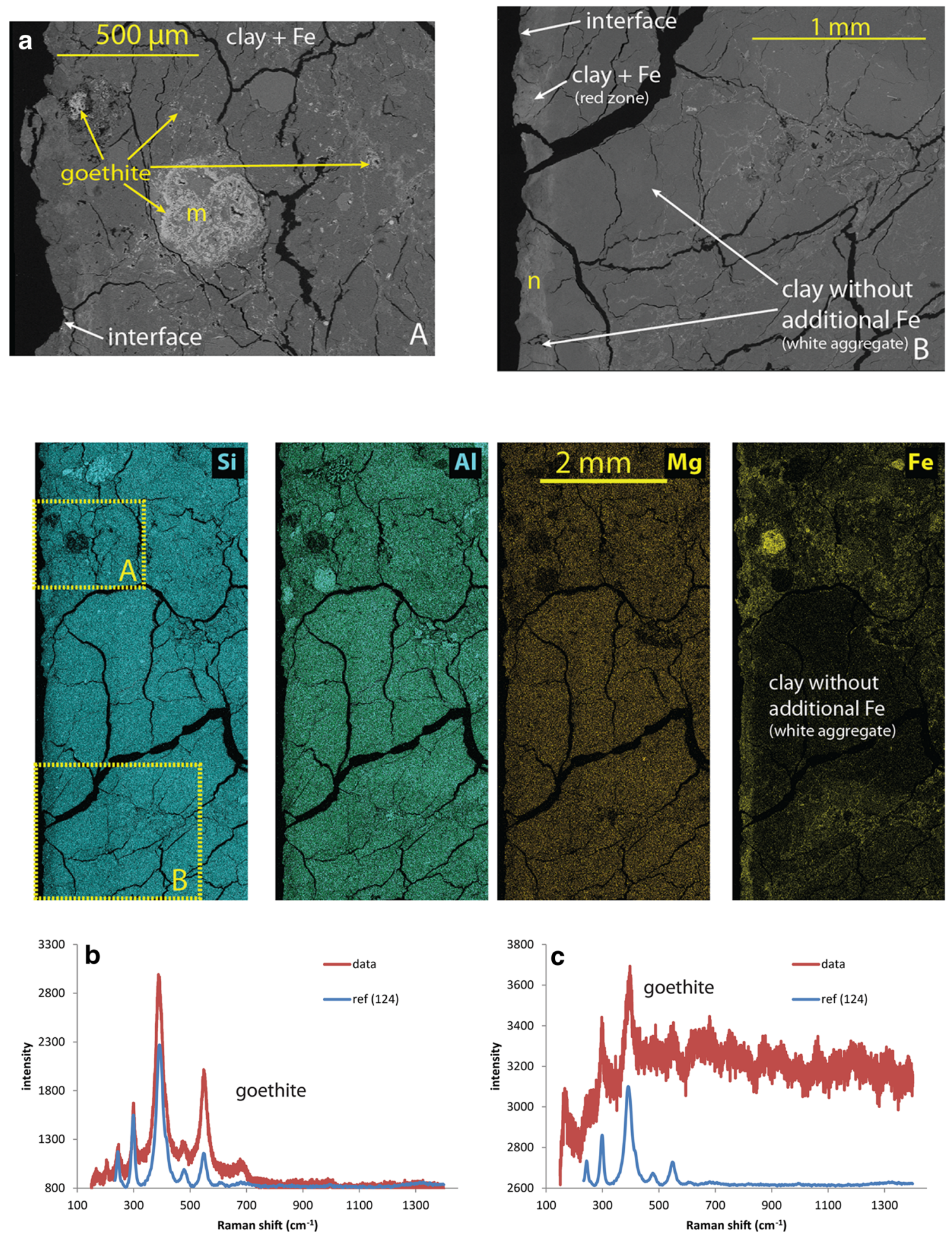

Fig. 7 (Upper) SEM pictures collected close to the interface between the FEBEX bentonite block and the steel liner. Letters indicate spots where Raman spectroscopy was performed (spectra shown in the bottom). (Middle) EDX mappings for the major elements in the same area. Positions of the two electronic pictures are indicated on the Si map. (Lower) Raman spectra collected at spots indicated in SEM picture

The sample made of white aggregates stands out from the sample sets. On the one hand, a larger amount of clay than the bulk raw material was observed, as was the case with the other light colored samples. On the other hand, this sample also 
Table 1 Minerals identified in the different samples extracted from the pristine FEBEX material (total raw material and colored aggregates) using XRD

\begin{tabular}{|c|c|c|c|c|c|c|c|c|}
\hline \multirow[t]{2}{*}{ Mineral(s) } & \multicolumn{8}{|c|}{ Sample } \\
\hline & raw & yellow & pink & white & green & red & black & blue \\
\hline $\mathrm{Mnt} / \mathrm{I}-\mathrm{S}^{\mathrm{a}}$ & +++ & ++++ & ++++ & ++++ & ++ & + & - & - \\
\hline Illite / mica & - & -- & + & - & - & ++ & +++ & ++ \\
\hline Quartz & + & + & + & + & ++ & +++ & ++++++ & +++++ \\
\hline Si-polymorphs ${ }^{\mathrm{b}}$ & - & - & - & + & ++ & +++ & +++ & ++++ \\
\hline Calcite & + & - & ++ & - & +++ & ++ & & +++ \\
\hline $\mathrm{Na} / \mathrm{K}$-feldspars & + & - & - & - & + & + & + & + \\
\hline $\mathrm{Na} / \mathrm{Ca}$-feldspars & - & + & - & -- & + & ++ & ++ & ++ \\
\hline Pyroxenes $^{c}$ & - & - & - & - & + & + & + & + \\
\hline Amorphous Si & -- & -- & -- & ++ & + & -- & -- & + \\
\hline
\end{tabular}

${ }^{a}$ montmorillonite or interstratified illite-smectite

b include cristobalite, tridymite, and opal CT

c include ideal pyroxene, pigeonite, and diopside

contained larger amounts of silica polymorphs (cristobalite, tridymite, opal CT) than the dark colored samples. In addition, the higher counts observed in the $20-23^{\circ} 2 \theta$ region accounted for the presence of amorphous silica.

\section{Domed XRD analysis of samples from block BM-B-41-1}

Data collected on 11 domed powdered samples from block BM-B-41-1 were compared and the diffractogram of the undomed raw material is displayed as a reference (Fig. 8). It must be emphasized that the raw material was analyzed undomed and as received (i.e. in standard conditions). The powdered samples from block BM-B-41-1 were analyzed after anaerobic preparation including freeze-drying followed by crushing and storing in rather dry conditions. These samples were analyzed under the dome, thus in slightly drier conditions compared to the undomed sample.

Reacted bentonite samples (excluding the crust) exhibited smaller basal spacing than the raw material, ranging from 12.2 (G30) to 13.7 (R2) $\AA$, with most samples displaying a similar value of $12.8 \AA$. The crust sample displayed a larger value of $14.8 \AA$, which was closer to the original value. This trend is consistent with the slight variation in the water content of the samples determined upon preparation for XRF measurements (drying at $105^{\circ} \mathrm{C}$ ), ranging from $3 \mathrm{wt} \%$ in $\mathrm{G} 30$ to $5 \mathrm{wt} . \%$ in

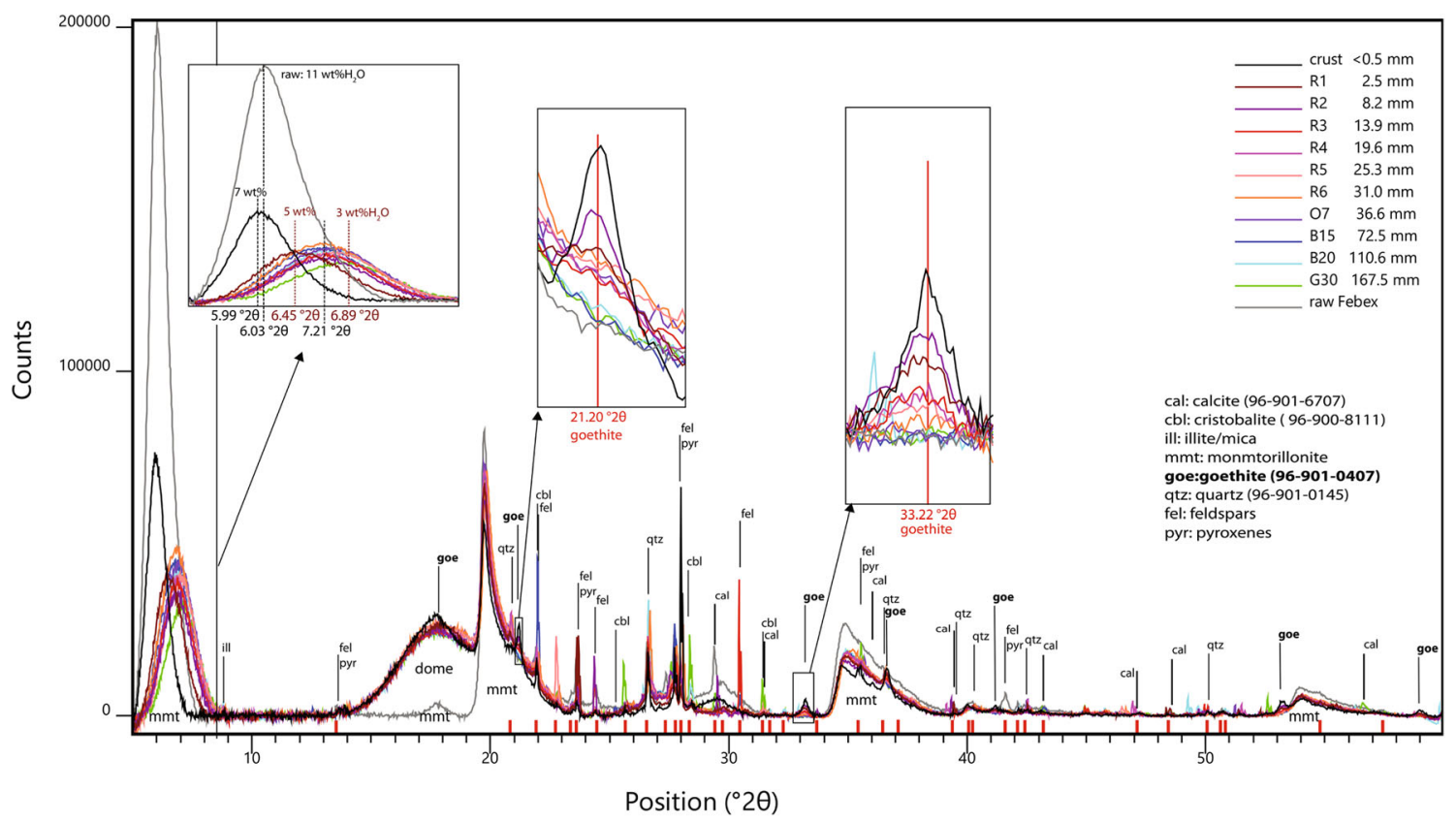

Fig. 8 Diffractograms of a series of powdered samples from block BM-B-41-1 (domed) and of the raw material (undomed) 
R2, with most of the samples containing $\sim 4$ wt. $\%$. The crust sample contained a slightly larger amount of water (7 wt.\%). The raw sample was more hydrated (11 wt.\%). Besides, the general observed drop in overall signal intensity was due to the presence of the dome. On the one hand, these results show no clear differences in basal spacing between the various samples retrieved from the FEBEX experiment (i.e. same spacing throughout the entire profile). On the other hand, a slight general decrease of the basal spacing was observed at the end of the experiment (compared to the raw material).

Besides slight changes in basal spacing and features related to the dome (the mount located around $17-18^{\circ} 2 \theta$ and the general drop in intensity), a number of differences were seen between the various samples above positions of $20^{\circ} 2 \theta$. A series of reflections was observed randomly in the retrieved samples, and were for a majority observed in the raw sample as well (indicated by red marks on the $x$ axis Fig. 8). These reflections can be attributed to single reflections from original accessory minerals (due to preferential orientation): calcite, silica polymorphs (quartz, cristobalite, tridymite, opal CT), illite, micas, pyroxenes, or feldspars.

A group of seven reflections was not observed in the raw material but only in a group of samples from the red area and from the crust. The positions of the reflections correspond to goethite, which proves that goethite accumulated in bentonite at distances within $40 \mathrm{~mm}$ of the interface. The goethite amount decreases progressively with increasing distance from the interface.

\section{${ }^{57} \mathrm{Fe}$ Mössbauer spectrometry (combined with XRF)}

Relative areas of the Mössbauer contributions (Figs. 9 and $\mathrm{S} 4$, Tables S3 and S4) are proportional to their relative amounts (i.e. correspond to fractions of total Fe). The Mössbauer data are, thus, combined with XRF data (absolute content of $\mathrm{Fe}$ ) to
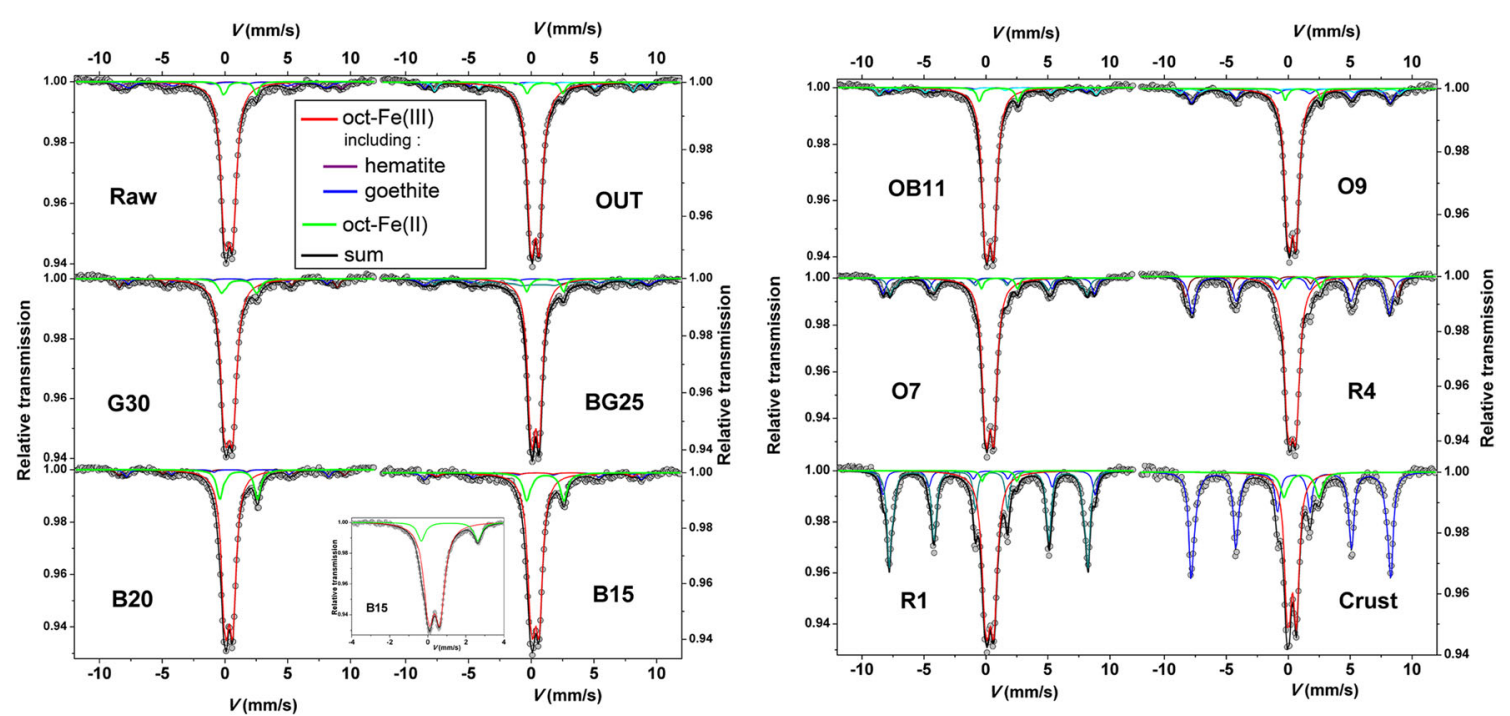

Fig. 977 K Mössbauer spectra of the raw FEBEX material and of the 11 samples from block BM-B-41-1. The refined values of the hyperfine parameters are listed in Tables S3 and S4 
and superparamagnetic species $\left(50-70 \mathrm{mmol}_{\mathrm{Fe}} \cdot \mathrm{kg}^{-1}\right)$ compared to the raw material, consisting of goethite and hematite (with a goethite:hematite ratio varying between 2:1 and 1:2). The proportion of paramagnetic Fe was, thus, generally greater than in the raw sample. The content of para-Fe(II) was very similar to that of the raw material $\left(20-25 \mathrm{mmol}_{\mathrm{Fe}} \cdot \mathrm{kg}^{-1}\right)$, except for sample BG25 which displayed a larger content $\left(44 \mathrm{mmol}_{\mathrm{Fe}} \cdot \mathrm{kg}^{-1}\right)$. These slight differences between this series of three samples and the raw material are attributed to natural variability within this bentonite material (varying goethitehematite distribution with regard to content and morphology).

The raw sample was selected from a separate pristine block, and its composition may, thus, slightly vary from the BM-B-41-1 block. Because the block studied should contain a more homogeneous composition, and because the outermost sample ('Out' sample, at a distance of $218 \mathrm{~mm}$ from the interface) was assumed to have been located far enough from the interaction zone (no color change, and total $\mathrm{Fe}$ content very similar to that of the raw material), this sample was, thus, considered as the pristine reference sample to assess changes in Fe speciation resulting from the corroding heater. Mössbauer data on Fe speciation from this sample were employed to calculate the additional $\mathrm{Fe}$ amounts in the other ones (Table 3 ). These additional contents were considered as representing the pool of $\mathrm{Fe}$ originating from the corroded liner. Results indicated no change in samples G30 and BG25, regarding the outermost samples. The larger content of para-Fe(II) in sample G30 was attributed to a slightly larger content of $\mathrm{Fe}^{2+}$-bearing accessory minerals from the initial matrix (illites, micas and/or ilmenite). The green-gray samples ('Out', G30, and BG25) were, thus, not impacted by corrosion of the steel liner.

Data collected on the blue samples B20 (111 mm from the interface) and B15 (82 $\mathrm{mm})$ were remarkably similar. The data indicated a content of magnetically ordered species very similar to the outermost samples, also with a goethite:hematite

Table 2 Fe distribution inferred by combining XRF (total Fe) and Mössbauer data (species distribution). Values in parentheses represent uncertainties

\begin{tabular}{|c|c|c|c|c|c|c|c|c|c|}
\hline \multirow[t]{5}{*}{ Sample name } & \multirow{5}{*}{$\begin{array}{l}\text { Distance from interface } \\
(\mathrm{mm})\end{array}$} & \multicolumn{8}{|c|}{ Absolute content } \\
\hline & & \multirow{4}{*}{$\begin{array}{l}\text { total } \mathrm{Fe}^{\mathrm{a}} \\
\left(\mathrm{mmol}_{\mathrm{Fe}} \cdot \mathrm{g}^{-1}\right.\end{array}$} & \multicolumn{7}{|c|}{ (species distribution) } \\
\hline & & & \multirow{3}{*}{$\begin{array}{l}\text { para-Fe(II) }{ }^{\mathrm{b}} \\
\left.{ }^{1}\right)\end{array}$} & \multirow[t]{3}{*}{ para-Fe(III) ${ }^{\mathrm{c}}$} & \multicolumn{5}{|c|}{ mag-Fe(III) ${ }^{\mathrm{d}}$} \\
\hline & & & & & \multirow[t]{2}{*}{ total mag ${ }^{\mathrm{e}}$} & \multicolumn{2}{|l|}{ goethite } & \multicolumn{2}{|l|}{ hematite } \\
\hline & & & & & & $\operatorname{large}^{\mathrm{f}}$ & medium $^{\mathrm{g}}$ & $\operatorname{large}^{\mathrm{f}}$ & medium $^{\mathrm{g}}$ \\
\hline \multicolumn{10}{|l|}{ Raw material } \\
\hline Raw & $\infty$ & $490(25)$ & $20(11)$ & $370(50)$ & $100(15)$ & $64(12)$ & $-10(10)$ & & $44(12)$ \\
\hline \multicolumn{10}{|c|}{ FEBEX samples } \\
\hline Crust & $<0.1$ & $1291(65)$ & $103(31)$ & 478 (157) & $710(61)$ & $697(61)$ & $13(61)$ & & \\
\hline R1 & 3 & $1078(54)$ & $22(23)$ & $463(128)$ & $593(51)$ & \multicolumn{2}{|c|}{$517(47)^{\mathrm{h}}$} & \multicolumn{2}{|c|}{$75(25)^{\mathrm{h}}$} \\
\hline $\mathrm{R} 4$ & 20 & $746(37)$ & $30(16)$ & $410(84)$ & $306(30)$ & \multirow[t]{2}{*}{$231(26)$} & $-15(26)$ & \multirow[t]{2}{*}{$104(20)$} & $-15(19)$ \\
\hline $\mathrm{O} 7$ & 37 & $651(33)$ & $20(14)$ & 449 (69) & $182(22)$ & & $104(18)$ & & $78(17)$ \\
\hline O9 & 48 & $683(34)$ & $27(15)$ & $485(71)$ & $171(22)$ & \multirow[t]{4}{*}{$27(15)$} & $116(21)$ & \multirow[t]{4}{*}{$20(15)$} & $7(15)$ \\
\hline OB11 & 59 & $540(27)$ & $34(12)$ & $436(54)$ & $70(14)$ & & 38 (13) & & $32(12)$ \\
\hline B15 & 82 & $544(27)$ & $87(15)$ & $403(56)$ & $54(14)$ & & $22(12)$ & & $33(13)$ \\
\hline B20 & 111 & $535(27)$ & $80(15)$ & $401(55)$ & $54(13)$ & & $32(12)$ & & $21(12)$ \\
\hline BG25 & 139 & $505(25)$ & $20(11)$ & $414(50)$ & $71(14)$ & \multicolumn{2}{|c|}{$20(11)^{\mathrm{h}}$} & \multicolumn{2}{|c|}{$50(13)^{\mathrm{h}}$} \\
\hline G30 & 168 & $486(24)$ & $44(12)$ & $394(48)$ & $49(12)$ & \multirow[t]{2}{*}{$34(11)$} & $-15(11)$ & \multirow[t]{2}{*}{$24(11)$} & $5(11)$ \\
\hline out & 218 & $495(25)$ & $25(11)$ & $416(49)$ & $54(13)$ & & $35(12)$ & & $20(11)$ \\
\hline \multicolumn{10}{|c|}{ a Measured by XRF, except for "crust" sample for which EDX data is used } \\
\hline \multicolumn{10}{|c|}{ b Paramagnetic Fe(II) (= total Fe(II) content) } \\
\hline \multicolumn{10}{|c|}{ c Paramagnetic Fe(III) (= total Fe - paramagnetic Fe(II) - magnetically ordered Fe(III)) } \\
\hline \multicolumn{10}{|c|}{ d Magnetically ordered Fe(III) } \\
\hline \multicolumn{10}{|c|}{ e $\mathrm{Fe}(\mathrm{III})$ in species magnetically ordered at $77 \mathrm{~K}$ (i.e. include medium- and large-sized species) } \\
\hline \multicolumn{10}{|c|}{${ }^{\mathrm{f}} \mathrm{Fe}(\mathrm{III})$ in species magnetically ordered at $300 \mathrm{~K}$} \\
\hline \multicolumn{10}{|c|}{${ }^{\mathrm{g}}$ Difference between contents at $77 \mathrm{~K}$ and at $300 \mathrm{~K}$} \\
\hline
\end{tabular}


Table 3 Additional Fe content relative to the pristine material, taking data from the outermost sample ( $218 \mathrm{~mm})$ as a reference (using data of Table 2). Values in parentheses represent uncertainties

\begin{tabular}{|c|c|c|c|c|c|c|c|c|c|}
\hline \multirow[t]{5}{*}{ Sample name } & \multirow{5}{*}{$\begin{array}{l}\text { Distance from interface } \\
(\mathrm{mm})\end{array}$} & \multicolumn{8}{|c|}{ Additional content } \\
\hline & & \multirow{4}{*}{$\begin{array}{l}\text { total } \mathrm{Fe} \\
\left(\mathrm{mmol}_{\mathrm{Fe}}\right)\end{array}$} & \multicolumn{7}{|c|}{ (species distribution) } \\
\hline & & & \multirow[t]{3}{*}{ para-Fe(II) } & \multirow[t]{3}{*}{ para-Fe(III) } & \multicolumn{5}{|c|}{ mag-Fe(III) } \\
\hline & & & & & \multirow[t]{2}{*}{ total mag } & \multicolumn{2}{|l|}{ goethite } & \multicolumn{2}{|l|}{ hematite } \\
\hline & & & & & & large & medium & large & medium \\
\hline \multicolumn{10}{|l|}{ Raw material } \\
\hline Raw & $\infty$ & $-5(49)$ & $-5(22)$ & $-46(99)$ & $46(27)$ & $64(13)$ & $-44(24)$ & & $24(23)$ \\
\hline \multicolumn{10}{|c|}{ FEBEX samples } \\
\hline Crust & $<0.1$ & $796(89)$ & $79(42)$ & $62(99)$ & $655(74)$ & $697(61)$ & $-22(61)$ & & $-20(11)$ \\
\hline $\mathrm{R} 1$ & 3 & $583(79)$ & $-3(34)$ & $48(205)$ & $538(64)$ & \multicolumn{2}{|c|}{$483(59)$} & \multicolumn{2}{|c|}{$56(36)$} \\
\hline R4 & 20 & $251(62)$ & $5(28)$ & $-6(132)$ & $251(43)$ & $231(26)$ & $-50(37)$ & $104(20)$ & $-35(30)$ \\
\hline $\mathrm{O} 7$ & 37 & $156(57)$ & $-5(25)$ & $33(117)$ & $128(35)$ & & $69(30)$ & & $58(28)$ \\
\hline O9 & 48 & $188(59)$ & $3(26)$ & $69(120)$ & $116(35)$ & $27(15)$ & $81(32)$ & $20(15)$ & $-13(26)$ \\
\hline OB11 & 59 & $45(52)$ & $9(24)$ & $20(102)$ & $16(27)$ & & $3(24)$ & & $13(23)$ \\
\hline B15 & 82 & $49(52)$ & $63(26)$ & $-13(105)$ & $0(26)$ & & $-13(24)$ & & $13(23)$ \\
\hline $\mathrm{B} 20$ & 111 & $40(52)$ & $56(26)$ & $-14(103)$ & $-1(26)$ & & $-3(24)$ & & $2(23)$ \\
\hline BG25 & 139 & $10(50)$ & $-4(22)$ & $-2(98)$ & $16(26)$ & -14 & (23) & 31 & (24) \\
\hline G30 & 168 & -9 (49) & $19(23)$ & $-22(97)$ & $-6(25)$ & 34 (11) & $-49(22)$ & $24(11)$ & $-15(22)$ \\
\hline
\end{tabular}

ratio of $1: 1$. The data also indicated an increase in the amount of para-Fe(II) of $60 \mathrm{mmol}_{\mathrm{Fe}} \cdot \mathrm{kg}^{-1}$, which is consistent with the observed increase in total $\mathrm{Fe}$ of $40-50 \mathrm{mmol}_{\mathrm{Fe}} \cdot \mathrm{kg}^{-1}$. In this case, the observed changes in Fe speciation and content (along with the blue color) are explained by the presence of additional $\mathrm{Fe}^{2+}$ from the corroding heater, which can be attributed to ferrous hydroxide, sorbed $\mathrm{Fe}^{2+}$, and/or sorbed $\mathrm{Fe}^{3+}$ following sorption of $\mathrm{Fe}^{2+}$ and reduction of clay structural $\mathrm{Fe}^{3+}$ (Gehin et al. 2007; Soltermann et al. 2013; Latta et al. 2017).

Data collected from sample OB11 (59 mm from the interface, at the transition between the orange and blue zones) indicated an increase in total $\mathrm{Fe}$ of $45 \mathrm{mmol}_{\mathrm{Fe}} \cdot \mathrm{kg}^{-1}$ relative to the outermost samples, similar to that in previous samples $\mathrm{B} 15$ and B20. In this case, however, this increase correlated with the additional presence of $20 \mathrm{mmol}_{\mathrm{Fe}} \cdot \mathrm{kg}^{-1}$ para-Fe(III) (Table 3) and $16 \mathrm{mmol}_{\mathrm{Fe}} \cdot \mathrm{kg}^{-1}$ mag-Fe(III) (in this case mainly goethite), and to the additional presence of $9 \mathrm{mmol}_{\mathrm{Fe}} \cdot \mathrm{kg}^{-1}$ para-Fe(II).

Samples O9, O7, R4, and R1 (originating from the orange and red area closer to the interface) differed even more from the three outermost samples, and displayed the same trend. The Mössbauer data indicated no net change in $\mathrm{Fe}^{2+}$ content (relative to the 'Out' reference sample), but a significantly higher content in magnetic oxides, mainly present as large-grained goethite, and to a lower extent as hematite and para Fe(III) (Table 3). In any case, the additional fraction of goethite is consistent with the additional content of total $\mathrm{Fe}$ inferred from
XRF data. This is also consistent with XRD data indicating the notable presence of goethite in this series of samples (from the interface to sample O7, Fig. 8), and consistent with the orangered coloration of the bentonite.

Finally, the crust sample displayed an even larger increase in total Fe content ( $220 \%$ increase). EDX data indicated an increase of at least $796 \mathrm{mmol}_{\mathrm{Fe}} \cdot \mathrm{kg}^{-1}$. This increase may be even higher because the value inferred above was averaged over the first $1.4 \mathrm{~mm}$ away from the contact with the steel liner (i.e. the first mapped row in the profile), while the crust sample originates from the first few hundred micrometers away from the steel liner. Mössbauer data indicated a significantly larger content of magnetically ordered species $\left(655 \mathrm{mmol}_{\mathrm{Fe}} \cdot \mathrm{kg}^{-1}\right.$, mainly large-sized goethite) and also a notably larger content of para $\mathrm{Fe}(\mathrm{II})\left(80 \mathrm{mmol}_{\mathrm{Fe}} \cdot \mathrm{kg}^{-1}\right.$ increase) and para-Fe(III) (62 $\mathrm{mmol}_{\mathrm{Fe}} \cdot \mathrm{kg}^{-1}$ increase) than the outermost samples. This is again consistent with XRD data indicating a significant amount of goethite in this sample. Most of the $\mathrm{Fe}(>70 \%)$ originates from the steel liner and consists mainly of large goethite grains $(>25 \mathrm{~nm})$. The small amounts of additional paramagnetic $\mathrm{Fe}^{3+}$ are also attributed to nano-goethite $(<5 \mathrm{~nm})$. The presence of other types of $\mathrm{Fe}^{3+}$-bearing phases, such as lepidocrocite or ferrihydrite, which exhibit magnetic ordering below $77 \mathrm{~K}$, cannot, however, be ruled out. The minor occurrence of hydrous Fe silicates cannot be ruled out either. The small amounts of additional paramagnetic $\mathrm{Fe}^{2+}$ might reflect similar species as occur in the green and blue zones, 
or also siderite. The presence of magnetite cannot be excluded, but it would be restricted to nanometer-sized paramagnetic particles, and is, thus, less likely (Murad and Cashion 2004).

Sample OB11 reflects a transient position between the blue and orange-red zones. Its additional $\mathrm{Fe}$ is present both as $\mathrm{Fe}^{3+}$ (mainly goethite) and $\mathrm{Fe}^{2+}$.

\section{DISCUSSION}

The study of Fe speciation in the original FEBEX matrix revealed that $\mathrm{Fe}$ is mainly $(75 \%)$ present as clay octahedral $\mathrm{Fe}^{3+}$. The other important forms consist of magnetically ordered goethite (up to 13\%) and superparamagnetic oxides (mainly hematite, $<9 \%$ ). A small portion (5\%) of paramagnetic $\mathrm{Fe}^{2+}$ is present initially, presumably in illite, mica minerals, ilmenite, or pyroxenes. Smectite is the main component of the bentonite (at least $75 \%$, interstratified I-S might in fact be present), and is more concentrated in the light colored parts of the matrix.

Post mortem analyses of the most-impacted block BM-B41-1 indicate that the main change noted at the end of the
FEBEX in situ test with regard to Fe is related to the diffusion of $\mathrm{Fe}$ into the bentonite from the steel liner.

The XRF profile of $\mathrm{Fe}$ as a function of distance from the interface with the liner gave clear evidence that a correlation exists between the coloration of the bentonite, the amount of additional $\mathrm{Fe}$, and the nature of the Fe species (Fig. 10). Although $\mathrm{Fe}$ accumulation is more obvious in the red-orange zone (first $45 \mathrm{~mm}$ from the steel liner contact), the data show that $\mathrm{Fe}$ diffused deeper into the bentonite, i.e. throughout the entire blue area. This is also supported by the slight difference between the EDX data on a large portion of the profile and the average bulk value in the outermost and, thus, less perturbed zone (by Fe diffusion) of the block (represented by the red line in Fig. 10). The value inferred from the EDX data is slightly less than the average XRF reference value (Kober and Van Meir 2017) but still falls within the error. The XRF data are in fact more consistent with the reference values, and the small differences observed between both Fe profiles indicate that the EDX data may underestimate slightly the true Fe content due to systematic errors in the EDX quantification.

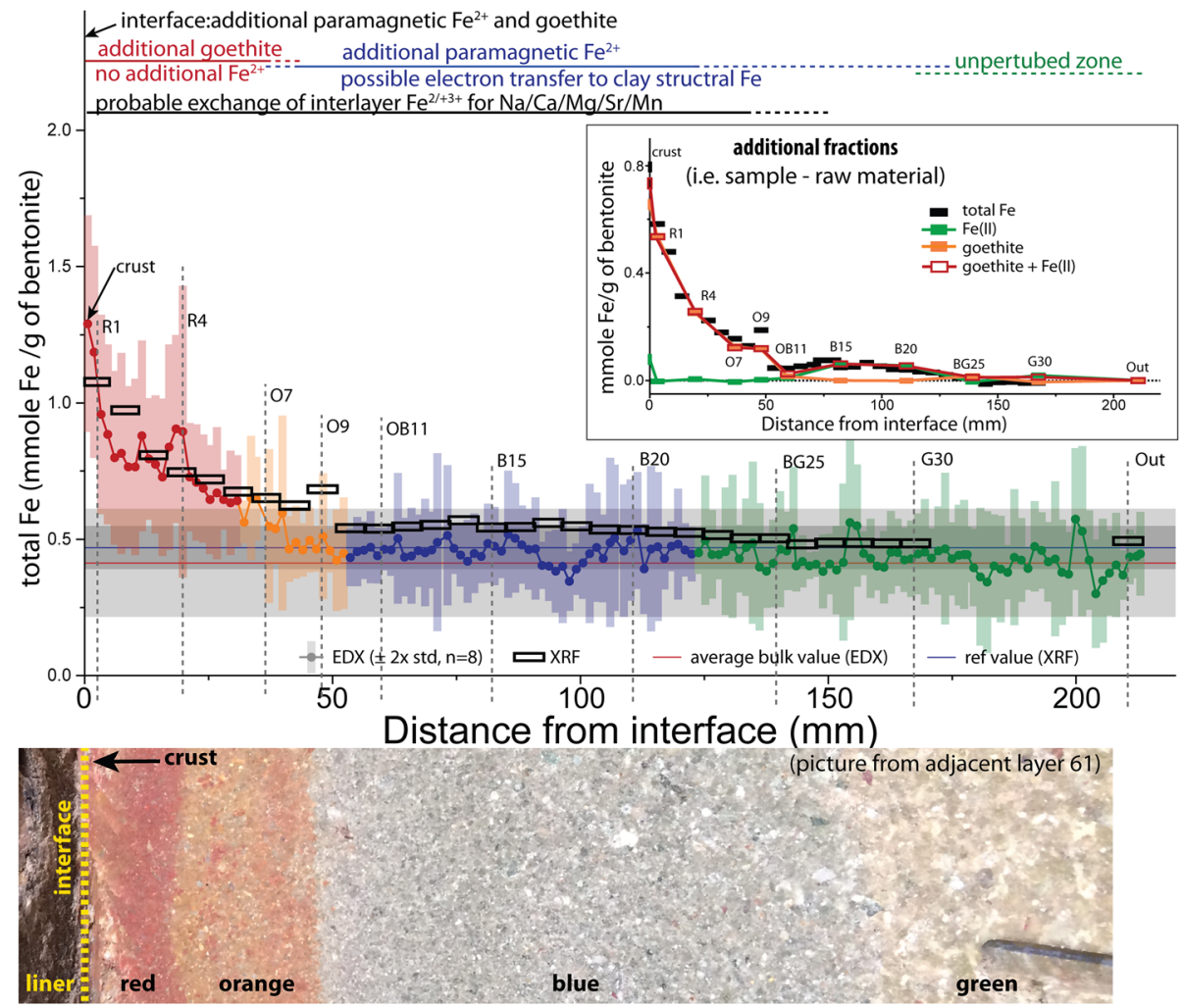

Fig. 10 Chemical profile of Fe perpendicular to the interface (here normalized by the $\mathrm{Al}$ atomic proportions) in block BM-B-41-1. Al normalized data were converted to mmol of Fe per gram of bentonite, using the weight content of Al in the original material (22.55 wt.\% Kober and Van Meir 2017) and a bulk dry density of $1.6 \mathrm{~g} \cdot \mathrm{cm}^{-3}$. The colors account for the color of the sampled powder. The blue line represents the average reference value in raw material, and the dark gray rectangle accounts for twice the standard deviation (Kober and Van Meir 2017). The horizontal red line represents the average value in the outermost zone of the block (at distances between 180 and $220 \mathrm{~mm}$ ), and the light gray rectangle accounts for twice the standard deviation. Vertical gray lines indicate the series of samples analyzed by Mössbauer spectrometry and XRD. The picture shows a bentonite block at the contact with the liner in adjacent layer 61 (chosen for its better photographic resolution); the extents of the various colored halos vary slightly (by a few $\mathrm{cm}$ ) from those in the block studied. The insert displays a chemical profile of "excess" portions (i.e. originating from the steel liner) of $\mathrm{Fe}(\mathrm{II})$, goethite, and total Fe as determined from XRF and Mössbauer data 


\section{Impact on bentonite chemistry}

Although clay (smectite or illite-smectite) makes up $>90 \%$ of the material, the granulometry of the FEBEX bentonite is quite heterogeneous, representing a large range from micrometer- to millimeter-sized aggregates of contrasting colors, scattered in a pale gray clay matrix. Dark-colored aggregates consist mostly of accessory minerals (silica polymorphs (quartz, cristobalite, opal CT), feldspar, pyroxene, olivine, oxides, carbonates, volcanic glass, etc.); while lightcolored ones (white, yellow, and pink) consist mostly of smectite. Chemical mappings show that Fe has been accumulated in the clay matrix at the boundary with the accessory minerals, but only in a portion of the clay-rich aggregates. Fe did not diffuse into the white aggregates. These white aggregates contrast clearly with the other light-colored ones because of their notable amorphous silica content, as indicated by XRD data on the powdered sample (Fig. 8 and Table 1). These aggregates might in fact consist of clay aggregates coated by a layer of amorphous silica which would deter $\mathrm{Fe}^{2+}$ from diffusing in.

Although $\mathrm{Fe}$ is expected to diffuse into the bentonite as $\mathrm{Fe}^{2+}$ $\left(\mathrm{Fe}^{3+}\right.$ being poorly soluble under the conditions of the experiment, i.e. $\mathrm{pH}$ of the bentonite medium $>6$ ), the data only indicate the presence of additional $\mathrm{Fe}^{2+}$ (in excess of the bentonite background level) in the crust (the first hundreds of micrometers) or much further away in the blue and green zone (at least at distances $>48 \mathrm{~mm}$ ). All the Fe accumulated in the red and orange zones is present mainly as goethite and hematite. The additional $\mathrm{Fe}$ found in the crust is also mainly as goethite. A small portion $(<10 \%)$ of additional $\mathrm{Fe}$ found in the most enriched zone (crust and red zone) is paramagnetic and could not be identified unambiguously. In that case, additional $\mathrm{Fe}^{3+}$ may be present in another type of (oxyhydr)oxide (lepidocrocite or ferrihydrite) or in hydrous $\mathrm{Fe}$ silicates. The identity of paramagnetic $\mathrm{Fe}^{2+}$-bearing species in the crust sample is still difficult to determine, although it could be siderite, magnetite, ferrous hydroxide, green rust, sorbed $\mathrm{Fe}^{2+}$, or reduced structural $\mathrm{Fe}$ (in the reduced clay). In the blue zone, Mössbauer data clearly only indicate the presence of paramagnetic $\mathrm{Fe}^{2+}$ in excess of the bentonite background level, with no net changes in $\mathrm{Fe}^{3+}$ content. Two processes can explain such a change in $\mathrm{Fe}$ redox speciation. Either $\mathrm{Fe}^{2+}$ is sorbed without electron transfer or an associated redox reaction with structural $\mathrm{Fe}^{3+}$ occurs, where structural $\mathrm{Fe}^{3+}$ is reduced and sorbed $\mathrm{Fe}^{2+}$ is oxidized. This would in fact result in no apparent net change in the amount of paramagnetic $\mathrm{Fe}^{3+}$. Eventual release of the sorbed $\mathrm{Fe}^{3+}$ would likely be followed by direct in situ precipitation of nanometer-sized goethite, and would have no impact on the amount of paramagnetic $\mathrm{Fe}^{3+}$. The presence of green rust, magnetite, or other mixed valence compounds can be ruled out because of the absence of additional $\mathrm{Fe}^{3+}$. However, the presence of $\mathrm{Fe}^{2+}$ as a separate phase such as siderite or ferrous hydroxide cannot be ruled out. The exact conditions and time sequence of the accumulation of $\mathrm{Fe}$ in the block BM-B-41-1 have not yet been determined. The reason for this asymmetric Fe diffusion front is explained by a clear contrast in the water saturation of the bentonite (Villar et al. 2017).

\section{A phenomenological description of the Fe diffusion mechanism}

The proposed mechanism is based on the interplay between the Fe released by the corrosion process of steel (diffusing Fe), the Fe initially present in the bentonite material (background $\mathrm{Fe}$ ), and the varying redox conditions.

The corrosion of steel in Fe-bentonite in situ experiments is believed to proceed in two steps. First, an aerobic step in which $\mathrm{Fe}^{3+}$ (and thus corrosion products) is generated at the surface of steel, and second, an anaerobic step (once $\mathrm{O}_{2}$ has been depleted from the system) where $\mathrm{Fe}^{2+}$ is generated (Kaufhold et al. 2015). This pathway is also confirmed by the analysis of the corrosion layer of the steel liner in the FEBEX experiment. The formation of goethite, hematite, and akaganeite as well as magnetite and siderite was identified (Madina 2016; Leal Olloqui and Scott 2017). Furthermore, Uyama et al. (2017) observed goethite and hematite partly replacing the thin magnetite layer initially present on the steel surface. Similar observations on the corrosion layer have been made in other in situ tests (Svensson and Hansen 2013; Wersin et al. 2015).

$\mathrm{Fe}^{2+}$ diffusion into bentonite is generally considered to occur during the anaerobic period and will mainly interact with the bentonite medium through ion exchange on basal surfaces (Xia et al. 2005; Wilson et al. 2015) and sorption to edge sites (Gehin et al. 2007; Soltermann et al. 2013; Muurinen et al. 2014; Latta et al. 2017). A monophasic diffusion of $\mathrm{Fe}^{2+}$ could, therefore, be expected. In fact, a biphasic diffusion front is generally observed, as in Xia et al. (2005) and in the present study. Here, a significant amount of additional $\mathrm{Fe}^{2+}$ is found at a greater distance from the interface, deeper in the bentonite, while $\mathrm{Fe}$ is mainly found as $\mathrm{Fe}^{3+}$ in the vicinity of the interface, up to several centimeters inside the bentonite.

One could argue that this large amount of $\mathrm{Fe}^{3+}$ would stem from a methodological artifact in the dismantling, subsampling, and analyzing approaches, i.e. that $\mathrm{Fe}^{2+}$ was present mainly in situ, but would have been oxidized prior to analysis. Partial oxidation of the sample studied cannot be ruled out. Nevertheless, the observed low reduction level of the additional Fe pool found close to the interface appears as a normal result of steel-bentonite interactions in such experimental settings. Similar observations were made in samples retrieved from analogous long-term experiments, such as the ABM2 experiment (Hadi et al. 2017). Because of the different shape, size, position, and the shorter dismantling time in the ABM2 experiment, less oxidative perturbation than in the FEBEX experiment should be expected (e.g. larger amounts of air circulation due to the presence of the gap between the liner and the heater).

The presence of a several centimeters wide $\mathrm{Fe}^{3+}$-rich, orange-colored bentonite rim right around a steel piece, surrounded by a larger and blue colored bentonite rim (Fe poorer, but more reduced) further away, was observed at various locations, such as the tips of both vertical and horizontal extensometers installed in the deeper section 54 or the fissurometers in section 43 of the FEBEX experiment (Fig. S3). In fact, this pattern appears to be the typical result of 
aerobic followed by anaerobic corrosion of steel enclosed in initially aerobic bentonite.

In the proposed mechanism, $\mathrm{Fe}^{2+}$ diffusion is first hindered by $\mathrm{O}_{2}$ present in the bentonite. $\mathrm{Fe}^{2+}$ is oxidized to $\mathrm{Fe}^{3+}$ and precipitates mainly as goethite as soon as it diffuses into the aerobic bentonite. $\mathrm{Fe}$ is, thus, first accumulated close to the interface, and will diffuse further in as soon as $\mathrm{O}_{2}$ is depleted in the bentonite. Although it cannot be completely ruled out, neo- formation of hydrous Fe silicates was not observed in any studied section of the FEBEX experiment, and is, thus, not taken into account in the proposed mechanism.

Diffusing $\mathrm{Fe}^{2+}$ can further interact with $\mathrm{Fe}$ initially present in the raw bentonite, which consists mainly of structural $\mathrm{Fe}^{3+}$ in octahedral smectite layers. This Fe is considered to be immobile but can undergo reversible redox reactions with the diffusing $\mathrm{Fe}^{2+}$, through the reduction by $\mathrm{Fe}^{2+}$ sorbed on the

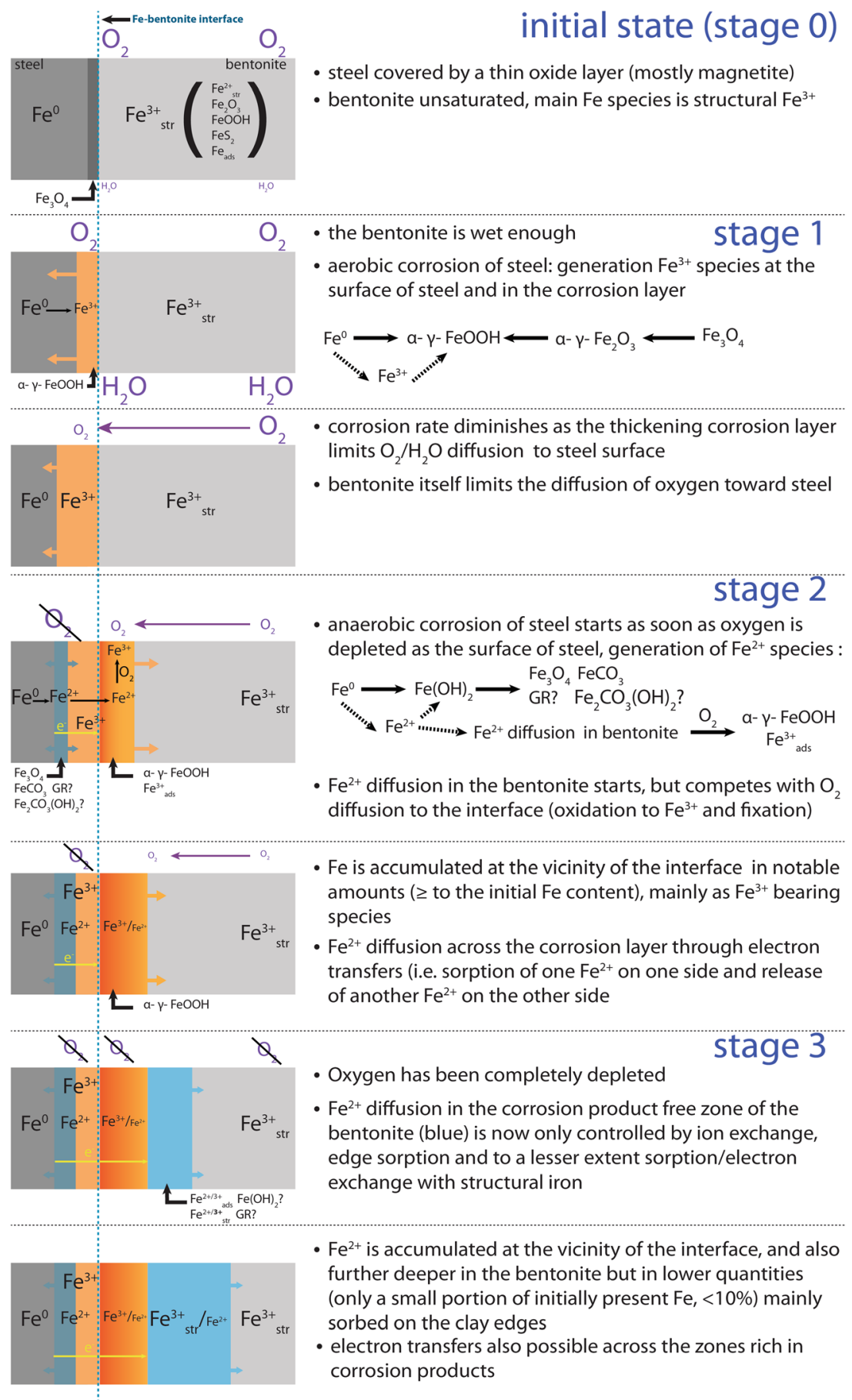

Fig. 11 Proposed Fe diffusion mechanism at the steel-bentonite interface 
edges (Schaefer et al. 2011; Soltermann et al. 2013, 2014), and also on basal surfaces (Komadel et al. 2006; Latta et al. 2017). Moreover, sorption of diffusing $\mathrm{Fe}^{2+}$ on pre-existing $\mathrm{Fe}^{3+}$ bearing oxides (e.g. on hematite (Yanina and Rosso 2008; Rosso et al. 2010; Kerisit et al. 2015) or goethite (Handler et al. 2014)) followed by an electron transfer inside the oxide and a release of $\mathrm{Fe}^{2+}$ from another crystallographic site is also possible. Redox interaction with the clay (edge or basal sorption and clay reduction) might lead to the formation of strongly sorbed $\mathrm{Fe}^{3+}$ and immobile structural $\mathrm{Fe}^{2+}$ (limited by the number of structural Fe(III) sites, i.e. at most $600 \mathrm{mmol} \cdot \mathrm{kg}^{-1}$ ). While sorption on oxides (followed by oxidation) leads to the fixation of $\mathrm{Fe}^{3+}$ in oxides, it also induces the release of mobile $\mathrm{Fe}^{2+}$ from another crystallographic plane (thus no net accumulation). Both processes will lead to retardation in Fe transport.

Following the proposed mechanism for Fe diffusion in the bentonite (Fig. 11), the additional $\mathrm{Fe}^{3+}$ is generated in situ, as $\mathrm{Fe}^{2+}$ starts to diffuse in the bentonite while low levels of oxygen in the clay are still present.

Results from experimental (Schlegel et al. 2014) and modeling (Wilson et al. 2015) studies show that the aerobic stage (stage 1 in Fig. 11) in a repository environment is generally short and would last less than a year under closed conditions as demonstrated from a lab-scale experiment (Kaufhold et al. 2015). As outlined in the introduction, the FEBEX experiment was not a closed system (potential pathways for air through the plug, the cable ducts, and the gas and water pipes, the effects of the dismantling of FEBEX I and the potential presence of fractures in the host rock). Nevertheless, various features related to anaerobic corrosion were observed throughout the samples. In particular, significant amounts of additional $\mathrm{Fe}^{2+}$ were found not only in the vicinity of the interface but also further away in the blue halo. This indicates that anaerobic conditions were reached during the FEBEX experiment. In the proposed mechanism (Fig. 11), diffusion of $\mathrm{Fe}^{2+}$ starts as soon as anaerobic conditions are reached at the surface of the steel and in the corrosion layer (stage 2). Aerobic conditions would still be prevailing in the bentonite. Most of the diffusing $\mathrm{Fe}^{2+}$ is, thus, oxidized and immobilized as soon as it enters the bentonite, mainly as $\mathrm{Fe}^{3+}$ paramagnetic oxides (e.g. goethite) and to a lesser extent as sorbed $\mathrm{Fe}^{3+}$ (actually $\mathrm{Fe}^{2+}$ is first sorbed and then oxidized by $\mathrm{O}_{2}$ ). During stage 2, the diffusion of $\mathrm{Fe}^{2+}$ inside the block, thus, competes with the diffusion of oxygen toward the interface. Diffusivity of $\mathrm{Fe}^{2+}$ would increase as soon as $\mathrm{O}_{2}$ concentration decreases. At some point (stage 3), $\mathrm{O}_{2}$ levels in the block become low enough to enable effective diffusion of $\mathrm{Fe}^{2+}$ over a larger distance in the clay. Diffusion of $\mathrm{Fe}^{2+}$ is then controlled by sorption onto clay minerals and by redox processes with structural $\mathrm{Fe}^{3+}$ in the clay or $\mathrm{Fe}^{3+}$ oxides (sorption followed by oxidation). The former process (sorption only) would be predominant, as sorption-reduction sites make up only a small portion of the sorption sites (at most $20 \%$ of the occupied octahedral sites are structural Fe (Grim and Kulbicki 1961; Gates 2005)). Either $\mathrm{Fe}^{2+}$ is sorbed without electron transfer or an associated redox reaction with structural $\mathrm{Fe}^{3+}$ occurs, in which structural $\mathrm{Fe}^{3+}$ is reduced and sorbed $\mathrm{Fe}^{2+}$ is oxidized. Under such conditions, $\mathrm{Fe}^{2+}$ diffuses further away from the interface and the local accumulation is more limited. The residence time of $\mathrm{Fe}^{2+}$ in the $\mathrm{Fe}^{3+}$-enriched zone close to the interface would be shortened, as the apparent diffusivity of $\mathrm{Fe}^{2+}$ would be enhanced by electron conduction through oxides. This can explain the absence of additional $\mathrm{Fe}^{2+}$ observed in the four samples collected in the red and orange zones close to the interface. As a consequence, this latter process would lead to a progressive tailing of the Fe profile. This means that the accumulation process of $\mathrm{Fe}^{3+}$ in the vicinity of the interface is stopped, and already-accumulated $\mathrm{Fe}^{3+}$ is slowly displaced further away from the interface.

It must be emphasized that the phenomena described were restricted to localized areas and did not occur all along the liner. The colored halos were observed only along a portion of the liner located in between the two heaters, and along other steel pieces located closer to the wall than to the heater. This is most likely related to varying water saturation conditions in the experiment. In the vicinity of the heaters, the bentonite was presumably not humid enough to allow such processes to occur. Strong contrast in water saturation (as measured in a neighboring layer (Villar et al. 2016)) may also explain the large differences between the two studied bentonite blocks and the resulting asymmetric corrosion halo (related to the leftover plastic sheet between the granitic host-rock and the lower part of this section of the experiment). These two blocks originated from the same section of the experiment, but the lower-most one (BM-B-42-2) was almost unaffected by corrosion of the steel liner. This is likely related to the leftover plastic sheet between the granitic host-rock and the lower part of this section of the experiment.

\section{CONCLUSION}

Eighteen years of steel-bentonite interaction in the FEBEX in situ test resulted in significant corrosion of emplaced metal components and migration of $\mathrm{Fe}$ inside the bentonite in some parts of the experiment, generating large visible red, orange, and blue colored halos. The combination of bulk and spatially resolved approaches employed in this study enabled characterization of the $\mathrm{Fe}$ diffusion front observed over $>140 \mathrm{~mm}$ inside a bentonite block. Goethite was the main newly formed Fe-bearing phase present in the red-orange zone present at the interface with steel (thus only additional $\mathrm{Fe}^{3+}$ ), while additional $\mathrm{Fe}^{2+}$ was found only at the very interface (few first hundreds of micrometers) and further into the wider and $\mathrm{Fe}$ poorer blue zone (without additional $\left.\mathrm{Fe}^{3+}\right)$. The exact location and speciation of this additional $\mathrm{Fe}^{2+}$ is, however, still to be determined. A mechanism is proposed where diffusion of $\mathrm{Fe}^{2+}$ only occurs as soon as anaerobic corrosion occurs (i.e. when $\mathrm{O}_{2}$ is depleted at the surface of steel) and sufficient water saturation conditions are met. Diffusion then proceeds in two stages. During the first stage, $\mathrm{Fe}^{2+}$ diffusion inside the bentonite competes with $\mathrm{O}_{2}$ diffusion toward the interface and $\mathrm{Fe}$ is 
accumulated as $\mathrm{Fe}^{3+}$ (oxyhydr)oxides (mainly goethite) in the vicinity of the interface. As soon as $\mathrm{O}_{2}$ is depleted inside the bentonite, $\mathrm{Fe}^{2+}$ can diffuse deeper into the clay. Better understanding of the process behind $\mathrm{Fe}$ accumulation in the bentonite also requires a good knowledge of pre-existing Fe-bearing phases. This combined SEM, XRD, Raman, and ${ }^{57} \mathrm{Fe}$ Mössbauer approach brings further refinement to pre-existing data on FEBEX bentonite.

\section{ACKNOWLEDGMENTS}

The authors thank Thomas Siegenthaler and Thomas Aebi for sample preparation. Andreas Jenni, Urs Mäder (University of Bern), and Florian Kober (Nagra) are acknowledged for fruitful discussions. The authors are grateful also to the three anonymous reviewers and the editorial team for careful handling of this manuscript. This work was partially supported by Nagra.

\section{REFERENCES}

Ackermann, F. (1980) A procedure for correcting the grain size effect in heavy metal analyses of estuarine and coastal sediments. Environmental Technology Letters, 1, 518-527.

ANDRA (2005) ANDRA research on the geological disposal of highlevel long-lived radioactive waste. Report Series, Dossier 2005, ANDRA, Paris, France, 40 pp. https://www.andra. fr/download/andra-international-en/document/editions/265.pdf

Ayari, F., Srasra, E., and Trabelsi-Ayadi, M. (2007) Effect of exchangeable cations on the physicochemical properties of smectite. Surface Engineering and Applied Electrochemistry, 43, 369-378.

Bradbury, M., Berner, U., Curti, E., Hummel, W., Kosakowski, G., and Thoenen, T. (2014) The long term geochemical evolution of the nearfield of the HLW repository. Nagra Technical Reports, TR 1201, Nagra, Villingen, Switzerland, 174 pp. https://www.nagra. $\mathrm{ch} /$ data/documents/database/dokumente/\$default/Default $\% 20$ Folder/Publikationen/NTBs\%202001-2010/e ntb12-01.pdf

Carlson, L., Karnland, O., Oversby, V.M., Rance, A.P., Smart, N.R., Snellman, M., Vahanen, M., and Werme, L.O. (2007) Experimental studies of the interactions between anaerobically corroding iron and bentonite. Physics and Chemistry of the Earth, 32, 334-345.

Eng, A.N.U. and Svensson, D. (2007) Äspö Hard Rock Laboratory Alternative Buffer Material - Installation report. International Progress Report, IPR-07-15, SKB, Stockholm, Sweden, 67 pp. http://skb.se/upload/publications/pdf/ipr-07-15.pdf

Fernandez, A.M., Baeyens, B., Bradbury, M., and Rivas, P. (2004) Analysis of the porewater chemical composition of a Spanish compacted bentonite used in an engineered barrier. Physics and Chemistry of the Earth, 29, 105-118.

Fuentes-Cantillana, J.L. and García-Siñeriz, J.L. (1998) FEBEX Fullscale engineered barriers experiment in crystalline host rock. Final design and installation of the "in situ" test at Grimsel. ENRESA Publicación Técnica, 12/98, ENRESA, Madrid, Spain, 182 pp. www.iaea.org/inis/collection/NCLCollectionStore/_Public/30/022 /30022753.pdf

Fuentes-Cantillana, J.L., García-Siñeriz, J.L., Obis, J., Pérez, A., Alberdi, J., Barcala, J.M., Campos, R., Cuevas, J., Fernández, A.M., Gamero, E., García, M., Gómez, P., Hernández, A., Illera, A., Martín, P.L., Melón, A.M., Mingarro, M., Ortuno, F., Pardillo, J., Pelayo, M., Rivas, P., Rodríguez, V., Turrero, M.J., Villar, M.V., Caballero, E., Jiménez de Cisneros, C., Linares, J., Martínez, M.A., Samper, J., Delgado, J., Juncosa, R., Molinero, J., Alonso, E., Carrera, J., Gens, A., García-Molina, A.J., Guimera, J., Guimaraes, L.d.N., Lloret, A., Martínez, L., Elorza, F.J., Borregón, J.L., Fariña, P., and Farias, J. (1998) FEBEX Full-scale engineered barriers experiment in crystalline host rock. pre-operational stage summary report. ENRESA Publicación Técnica, 1/98, ENRESA, Madrid, Spain, 390 pp.
Fuentes-Cantillana, J.L., García-Siñeriz, J.L., Franco, J.J., Obis, J., Pérez, A., Jullien, F., Alberdi, J., Barcala, J.M., Campos, R., Cuevas, J., Fernández, A.M., Gamero, E., García, M., Gómez, P., Hernández, A., Illera, A., Martín, P.L., Melón, A.M., Missana, T., Ortuno, F., Pardillo, J., Rivas, P., Turrero, M.J., Villar, M.V., Mingarro, M., Pelayo, M., Caballero, E., Cuadros, J., Huertas, F., Huertas, F.J., Jiménez de Cisneros, C., Linares, J., Bazargan-Sabet, B., Ghoreychi, M., Jockwer, N., Wieczorek, K., Kickmaier, W., Marschall, P., Martínez, M.A., Carretero, P., Dai, Z., Delgado, J., Juncosa, R., Molinero, J., Ruiz, A., Samper, J., Vázquez, A., Alonso, E., Carrera, J., Gens, A., GarcíaMolina, A.J., Guimera, J., Guimaraes, L.d.N., Lloret, A., Martínez, L., Olivella, S., Pintado, X., Sánchez, M., Elorza, F.J., Borregón, J.L., Canamon, I., Rodriguez Pons-Esparver, R., Fariña, P., Farias, J., and Huertas, F. (2000) FEBEX project: full-scale engineered barriers experiment for a deep geological repository for high level radioactive waste in crystalline host rock. Final report ENRESA Publicación Técnica, 1/2000, ENRESA, Madrid, Spain, 367 pp. http://www.iaea. org/inis/collection/NCLCollectionStore/_Public/31/033/31033797.pdf

Gates, W.P. (2005) Infrared spectroscopy and the chemistry of dioctahedral smectites. Pp. 126-168 in: The Application of Vibrational Spectroscopy to Clay Minerals and Layered Double Hydroxides (J.T. Kloprogge, editor), 13, The Clay Minerals Society, Aurora, Colorado, USA.

Gaudin, A., Gaboreau, S., Tinseau, E., Bartier, D., Petit, S., Grauby, O., Foct, F., and Beaufort, D. (2009) Mineralogical reactions in the Tournemire argillite after in-situ interaction with steels. Applied Clay Science, 43, 196-207.

Gehin, A., Greneche, J.M., Tournassat, C., Brendle, J., Rancourt, D.G., and Charlet, L. (2007) Reversible surface-sorption-induced electron-transfer oxidation of $\mathrm{Fe}$ (II) at reactive sites on a synthetic clay mineral. Geochimica et Cosmochimica Acta, 71, 863-876.

Grim, R.E. and Kulbicki, G. (1961) Montmorillonite: high temperature reactions and classification. American Mineralogist, 46, 1329 1369.

Gütlich, P., Bill, E., and Trautwein, A.X. (2011) Mössbauer Spectroscopy and Transition Metal Chemistry. Springer-Verlag, Berlin Heidelberg, Germany.

Hadi, J., Wersin, P., Jenni, A., and Greneche, J.M. (2017) Redox evolution and Fe-bentonite interaction in the ABM2 experiment, Äspö Hard Rock Laboratory. Nagra Technischer Bericht, NAB 1710, Nagra, Wettingen, Switzerland, 304 pp. https://www.nagra. $\mathrm{ch} /$ data/documents/database/dokumente/\$default/Default $\% 20$ Folder/Publikationen/NTBs\%202014\%20-\%202015/e_ntb17-10. pdf

Handler, R.M., Frierdich, A.J., Johnson, C.M., Rosso, K.M., Beard, B.L., Wang, C., Latta, D.E., Neumann, A., Pasakarnis, T., and Premaratne, W.A.P.J. (2014) Fe(II)-Catalyzed recrystallization of goethite revisited. Environmental Science \& Technology, 48, 11302-11311.

Huertas, F., Farinia, P., Farias, J., Garcia-Sineriz, J.L., Villar, M.V., Fernandez, A.M., Martin, P.L., Elorza, F.J., Gens, A., Sanchez, M., Lloret, A., Samper, J., and Martinez, M.A. (2006) Full-scale engineered barriers experiment. Updated final report 1994-2004. ENRESA Publicación Técnica, 05-0/2006, ENRESA, Madrid, Spain, 590 pp.

Karnland, O., Olsson, S., Dueck, A., Birgersson, M., Nilsson, U., and Hernan-Hakansson, T. (2009) Long term test of buffer material at the Äspö Hard Rock Laboratory, LOT project. Final report on the A2 test parcel. SKB Technical Report, TR-09-29, SKB, Stockholm, Sweden, 279 pp. http://www.skb.se/upload/publications/pdf/TR09-29.pdf

Kaufhold, S., Hassel, A.W., Sanders, D., and Dohrmann, R. (2015) Corrosion of high-level radioactive waste iron-canisters in contact with bentonite. Journal of Hazardous Materials, 285, 464-473.

Kerisit, S., Zarzycki, P., and Rosso, K.M. (2015) Computational Molecular Simulation of the Oxidative Adsorption of Ferrous Iron at the Hematite (001)-Water Interface. The Journal of Physical Chemistry C, 119, 9242-9252.

Kober, F., Giroud, N., Uyama, M., Hitomi, T., Hayagane, S., Kadota, N., Saito, H., Okamoto, S., Aoshima, K., Osawa, M., Hadi, J., 
Grenèche, J.M., Wersin, P., Svensson, D., Lundgren, C., Kaufhold, S., Dohrmann, R., Ufer, K., Torres, E., Turrero, M.J., Sánchez, L., Garralón, A., Gómez, P., Campos, R., Leal Olloqui, M., Scott, T.B., and Madina, V. (2017) FEBEX-DP. Metal Corrosion and IronBentonite Interaction Studies. Nagra Arbeitsbericht, NAB 16-16, Nagra, Wettingen, Switzerland, 300 pp. http://www.grimsel. com/febex-dp-generalfiles/351-nab-16-016-metal-corrosion-andiron-bentonite-interaction-studies-1

Kober, F., Giroud, N., Uyama, M., Hitomi, T., Hayagane, S., Kadota, N., Saito, H., Okamoto, S., Aoshima, K., Osawa, M., Hadi, J., Grenèche, J.M., Wersin, P., Svensson, D., Lundgren, C., Kaufhold, S., Dohrmann, R., Ufer, K., Torres, E., Turrero, M.J., Sánchez, L., Garralón, A., Gómez, P., Campos, R., Leal Olloqui, M., Scott, T.B., and Madina, V. (2017) FEBEX-DP. Metal Corrosion and Iron-Bentonite Interaction Studies. Nagra Arbeitsbericht, NAB 16-16, Nagra, Wettingen, Switzerland, 300 pp. http://www.grimsel. com/febex-dp-general-files/351-nab-16-016-metal-corrosion-andiron-bentonite-interaction-studies-1

Komadel, P., Madejová, J., and Stucki, J.W. (2006) Structural Fe(III) reduction in smectites. Applied Clay Science, 34, 88-94.

Lábár, J.L. and Török, S. (1992) A peak-to-background method for electron probe X-ray micro-analysis applied to individual small particles. X-Ray Spectrometry, 21, 183-190.

Lafuente, B., Drowns, R.T., Yang, H., and Stone, N. (2015) The power of databases: the RRUFF project. Pp. 1-30 in: Highlights in Mineralogical Chrystallography (T. Armbruster and R.M. Danisi, editors). De Gruyter, Berlin, Germany.

Lantenois, S., Lanson, B., Muller, F., Bauer, A., Jullien, M., and Plançon, A. (2005) Experimental study of smectite interaction with metal Fe at low temperature: 1 . Smectite destabilization. Clays and Clay Minerals, 53, 597-612.

Lanyon, G.W. and Gaus, I. (2017) Main outcomes and review of the FEBEX In Situ Test (GTS) and Mock-up after 15 years of operation. Nagra Technischer Bericht, NTB 15-04, Nagra, Wettingen, Switzerland, 127 pp. https:/www.nagra.ch/data/documents/database/ dokumente/\$default/Default\%20Folder/Publikationen/NTBs\%20201 4\%20-\%202015/e_ntb15-04.pdf

Latta, D.E., Neumann, A., Premaratne, W.A.P.J., and Scherer, M.M. (2017) Fe(II)-Fe(III) Electron Transfer in a Clay Mineral with Low Fe Content. ACS Earth and Space Chemistry, 1, 197-208.

Leal Olloqui, M. and Scott, T.B. (2017) Study of the University of Bristol. Pp. 158-187 in: FEBEX-DP. Metal Corrosion and IronBentonite Interaction Studies (P. Wersin and F. Kober, editors). NAB 16-016, Nagra, Wettingen, Switzerland.

Luoma, S.N. (1990) Processes affecting metal concentrations in estuarine and coastal marine sediments. Pp. 51-66 in: Heavy Metals in Marine Environment (R.W. Furness and P.S. Rainbow, editors). CRC Press Inc., Boca Raton, Florida, USA.

Madina, V. (2016) Corrosion Study of FEBEX DP Components. Nagra Arbeitsbericht, NAB 16-054, Nagra, Wettingen, Switzerland, 107 pp. http://www.grimsel.com/febex-dp-generalfiles/356-nab-16-054-corrosion-study-of-febex-dp-components-1

Martín, P.L., Barcala, J.M., and García-Gutiérrez, M. (2006) Thermohydro-mechanical Instrumentation in a Long-term Large-scale Buffer Material Test: Mock-up Experiment at CIEMAT. Pp. 577584 in: proceedings of 5th ICEG Environmental Geotechnics: Opportunities, Challenges and Responsibilities for Environmental Geotechnics, Cardiff, United Kingdom, 2006, Thomas Telford Pub.

Martin, F.A., Bataillon, C., and Schlegel, M.L. (2008) Corrosion of iron and low alloyed steel within a water saturated brick of clay under anaerobic deep geological disposal conditions: An integrated experiment. Journal of Nuclear Materials, 379, 80-90.

Marty, N.C.M., Fritz, B., Clement, A., and Michau, N. (2010) Modelling the long term alteration of the engineered bentonite barrier in an underground radioactive waste repository. Applied Clay Science, 47, 82-90.

Mössbauer, R.L. (1958) Kernresonanzabsorption von Gammastrahlung in Ir191. Naturwissenschaften, 45, 538-539.

Mosser-Ruck, R., Cathelineau, M., Guillaume, D., Charpentier, D., Rousset, D., Barres, O., and Michau, N. (2010) Effects of temperature, $\mathrm{pH}$, and iron/clay and liquid/clay ratios on experimental conversion of dioctahedral smectite to berthierine, chlorite, vermiculite, or saponite. Clays and Clay Minerals, 58, 280-291.

Murad, E. and Cashion, J.D. (2004) Mössbauer Spectroscopy of Environmental Materials and their Industrial Utilization. Kluwer Academic Publishers, Dordrecht, Netherlands.

Muurinen, A., Tournassat, C., Hadi, J., and Greneche, J.M. (2014) Sorption and diffusion of Fe(II) in bentonite. Posiva Working Reports, WR-2014-04, Posiva, Olkiluoto, Finland, 84 pp. http://www.posiva.fi/files/3772/WR_2014-04.pdf

Nagra (2002) Project Opalinus Clay: Safety report. Demonstration of disposal feasibility for spent fuel, vitrified high-level waste and longlived intermediate-level waste (Entsorgungsnachweis). Nagra Technischer Bericht, NTB 02-05, Nagra, Wettingen, Switzerland, 24 pp. http://www.nagra.ch/data/documents/database/dokumente/\$default/ Default\%20Folder/Publikationen/NTBs\%202001-2010/e_ntb02-05. pdf

Papillon, F., Jullien, M., and Bataillon, C. (2003) Carbon steel behaviour in compacted clay: two long-term tests for corrosion prediction. Pp. 439-454 in: proceedings of Prediction of Long Term Corrosion Behaviour in Nuclear Waste Systems (International Workshop), Maney Publishing, Cadarache, France, 2002.

Perronnet, M., Jullien, M., Villieras, F., Raynal, J., Bonnin, D., and Bruno, G. (2008) Evidence of a critical content in $\mathrm{Fe}(0)$ on FoCa7 bentonite reactivity at 80 degrees C. Applied Clay Science, 38, 187-202.

Posiva (2012) Safety case for the disposal of spent nuclear fuel at Olkiluoto - Synthesis 2012 Posiva Reports, 2012-12, Posiva, Olkiluoto, Finland, 324 pp. http://www.posiva.fi/files/2987 /Posiva 2012-12web.pdf

Rosso, K.M., Yanina, S.V., Gorski, C.A., Larese-Casanova, P., and Scherer, M.M. (2010) Connecting observations of hematite (alpha$\mathrm{Fe}_{2} \mathrm{O}_{3}$ ) growth catalyzed by $\mathrm{Fe}(\mathrm{II})$. Environmental Science \& Technology, 44, 61-67.

Schaefer, M.V., Gorski, C.A., and Scherer, M.M. (2011) Spectroscopic evidence for interfacial $\mathrm{Fe}(\mathrm{II})-\mathrm{Fe}(\mathrm{III})$ electron transfer in a clay mineral. Environmental Science \& Technology, 45, 540-545.

Schlegel, M.L., Bataillon, C., Blanc, C., Pret, D., and Foy, E. (2010) Anodic activation of iron corrosion in clay media under watersaturated conditions at 90 degrees $\mathrm{C}$ : characterization of the corrosion interface. Environmental Science \& Technology, 44, 15031508.

Schlegel, M.L., Bataillon, C., Brucker, F., Blanc, C., Pret, D., Foy, E., and Chorro, M. (2014) Corrosion of metal iron in contact with anoxic clay at 90 degrees C: Characterization of the corrosion products after two years of interaction. Applied Geochemistry, 51, $1-14$.

SKB (2011) Long-term safety for the final repository for spent nuclear fuel at Forsmark. Main report of the SR-Site project. Volume II. SKB Tecnical Reports, TR-11-01, SKB, Stockholm, Sweden, 278 pp. http://skb.se/upload/publications/pdf/TR-11-01_vol2.pdf

Soltermann, D., Fernandes, M.M., Baeyens, B., Dahn, R., MieheBrendle, J., Wehrli, B., and Bradbury, M.H. (2013) Fe(II) sorption on a synthetic montmorillonite. A combined macroscopic and spectroscopic study. Environmental Science \& Technology, 47, 69786986.

Soltermann, D., Fernandes, M.M., Baeyens, B., Dahn, R., Joshi, P.A., Scheinost, A.C., and Gorski, C.A. (2014) Fe(II) uptake on natural montmorillonites. I. Macroscopic and spectroscopic characterization. Environmental Science \& Technology, 48, 8688-8697.

Stucki, J.M. (2006) Properties and behaviour of iron in clay minerals. Pp. 423-476 in: Handbook of Clay Science (F. Bergaya, B.K.G. Theng, and G. Lagaly, editors). Elsevier, Amsterdam, Netherlands. Svensson, P.D. and Hansen, S. (2013) Redox chemistry in two ironbentonite field experiments at Äspö Hard Rock Laboratory, Sweden: an XRD and Fe k-edge XANES study. Clays and Clay Minerals, 61, 566-579.

Svensson, D., Dueck, A., Nilsson, U., Olsson, S., Sandén, T., Lydmark, S., Jägerwall, S., Pedersen, K., and Hansen, S. (2011) Alternative buffer material - Status of the ongoing laboratory investigation of reference materials and test package 1. SKB Technical Reports, SKB 
TR-11-06, SKB, Stockholm, Sweden, 140 pp. http://www.skb. se/upload/publications/pdf/TR-11-06.pdf

Trincavelli, J., Limandri, S., and Bonetto, R. (2014) Standardless quantification methods in electron probe microanalysis. Spectrochimica Acta Part B: Atomic Spectroscopy, 101, 76-85.

Tzara, C. (1961) Diffusion des photons sur les atomes et les noyaux dans les cristaux. Journal de Physique et Le Radium, 22, 303-307.

Uyama, M., Hitomi, T., Hayagane, S., Kadota, N., Saito, H., Okamoto, S., Aoshima, K., and Osawa, M. (2017) Metal corrosion analysis by Obayashi. Pp. 29-51 in: FEBEX-DP. Metal Corrosion and IronBentonite Interaction Studies (P. Wersin and F. Kober, editors). NAB 16-016, Nagra, Wettingen, Switzerland.

Vandenberghe, R. and De Grave, E. (2013) Application of Mössbauer Spectroscopy in Earth Sciences. Pp. 91-185 in: Mössbauer Spectroscopy - Tutorial book (Y. Yoshida and G. Langouche, editors). Springer-Verlag, Berlin Heidelberg, Germany.

Villar, M.V., Fernández, A.M., Rivas, P., Lloret, A., Daucausse, D., Montarges-Pelletier, E., Devineau, K., Villieras, F., Hynková, E., Cechova, Z., Montenegro, L., Samper, J., Zheng, L., Robinet, J.C., Muurinen, A., Weber, H.P., Börgesson, L., Sandén, T., and Verstricht, J. (2006) FEBEX Project final report - Post-mortem bentonite analysis. ENRESA Publicación Técnica, 05-1/2006, ENRESA, Madrid, Spain, 200 pp.

Villar, M.V., Iglesias, R.J., Abós, H., Martínez, V., de la Rosa, C., and Manchón, M.A. (2016) FEBEX-DP on-site analyses report. Nagra Arbeitsbericht, NAB 16-12, Nagra, Wettingen, Switzerland, 115 pp. http://www.grimsel.com/febex-dp-general-files/349-nab-16012-febex-dp-on-site-analyses-report

Villar, M.V., Fernández, A.M., Romero, E., Dueck, A., Cuevas, J., Plötze, M., Kaufhold, S., Dohrmann, R., Iglesias, R.J., Sakaki, T., Zheng, L.,
Kawamoto, K., and Kober, F. (2017) FEBEX DP Post mortem THM THG Analysis Report. Nagra Arbeitsbericht, NAB 16-17, Nagra, Wettingen, Switzerland, $187 \mathrm{pp}$. https://www.nagra. $\mathrm{ch} /$ data/documents/database/dokumente/\$default/Default $\% 20$ Folder/Publikationen/NABs\%202004\%20-\%202015/e nab16-017.pdf Wersin, P., Johnson, L., and Schwyn, B. (2004) Assessment of redox conditions in the near field of nuclear waste repositories: Application to the Swiss high-level and intermediate level waste disposal concept. Pp. 539-544 in: Proceedings of Scientific Basis for Nuclear Waste Management XXVII, Kalmar, Sweden, 2003, Materials Research Society.

Wersin, P., Birgersson, M., Olsson, S., Karnland, O., and Snellman, M. (2008) Impact of corrosion-derived iron on the bentonite buffer within the KBS-3H disposal concept - the Olkiluoto site as case study. Posiva Reports, 2007-11, Posiva, Olkiluoto, Finland, 58 pp. http://www.posiva.fi/files/807/POSIVA2007-11web_16.2.09.pdf

Wersin, P., Jenni, A., and Mäder, U.K. (2015) Interaction of corroding iron with bentonite in the ABM1 experiment at Äspö, Sweden: a microscopic approach. Clays and Clay Minerals, 63, 51-68.

Wilson, J.C., Benbow, S., Sasamoto, H., Savage, D., and Watson, C. (2015) Thermodynamic and fully-coupled reactive transport models of a steel-bentonite interface. Applied Geochemistry, 61, 10-28.

Xia, X., Idemitsu, K., Arima, T., Inagaki, Y., Ishidera, T., Kurosawa, S., Iijima, K., and Sato, H. (2005) Corrosion of carbon steel in compacted bentonite and its effect on neptunium diffusion under reducing condition. Applied Clay Science, 28, 89-100.

Yanina, S.V. and Rosso, K.M. (2008) Linked reactivity at mineralwater interfaces through bulk crystal conduction. Science, 320, 218 222. 